\title{
Benzoannelated [2.2]Paracyclophanes: Synthesis and Electronic Properties
}

\author{
Oliver Reiser, ${ }^{\dagger}$ Burkhard König, ${ }^{\dagger}$ Klaus Meerholz, $\ddagger$ Jürgen Heinze, ${ }^{*} \ddagger$ Thomas Wellauer, $\$$ \\ Fabian Gerson, $\$$ Ron Frim, Mordecai Rabinovitz," and Armin de Meijere ", \\ Contribution from the Institut für Organische Chemie der Universität Hamburg, \\ Martin-Luther-King-Platz 6, 2000 Hamburg, Germany, Department of Chemistry, \\ Hebrew University Jerusalem, Jerusalem, Israel, Institut für Physikalische Chemie der \\ Universität Freiburg, Albertstrasse 21, 7800 Freiburg, Germany, and Institut für Physikalische \\ Chemie der Universität Basel, Klingelbergstrasse 80, 4056 Basel, Switzerland
}

Received November 18, 1992

\begin{abstract}
Mono- and dibenzoannelated [2.2]paracyclophanes 12 and 1 were synthesized by palladium-catalyzed twoand four-fold alkenylation of vicinal di- and tetrabromides 5 and 6, respectively, and subsequent electrocyclization/ dehydrogenation of the resulting $(E, Z, E)$-trienes. Further extensions of the annelated ring systems, leading to the tetrahydronaphthalene derivative 15, the bis-terphenylene derivative 16, and the benzobis[2.2] paracyclophane 18, were achieved through derivatization of suitable substituents introduced with the alkene coupling component. Mono- and polyanions of some derivatives were generated and studied by ESR, ENDOR, and NMR spectroscopy, as well as by cyclic voltammetry. The assembly of mutually orthogonal $\pi$-systems in arene annelated [2.2] paracyclophanes allows the reversible incorporation of up to six additional electrons per molecule, which is the upper limit for hydrocarbons reported to date.
\end{abstract}

\section{Introduction}

It has long been recognized that electron-transfer phenomena play a fundamental role in biology as well as in chemistry. ${ }^{1}$ Consequently, considerable efforts have been made to study the mechanisms which involve electron-transfer steps. Traditionally, it has been believed that conjugated $\pi$-systems are essential for the efficient movement of electrons through molecules. However, recent studies have suggested ${ }^{2}$ that electron transfer through a $\sigma$-framework might also be effective.

We have been interested in the electronic properties of compounds with mutually orthogonal $\pi$-systems such as dibenzoannelated [2.2] paracyclophanes of the general structure 1 . These molecules consist of four biphenyl units, which are held rigidly in a perpendicular conformation and are, therefore, a priori nonconjugated. By studying anions of these molecules by ESR and NMR spectroscopy, as well as by cyclic voltammetry, we hoped to address two questions:

(1) Are the $\pi$-systems in the arene subunits of 1 sufficiently isolated to be reduced independently? (2) Do they interact sufficiently to allow electron transfer between them? This way, polyanions of 1 could serve as models for an electron storage system.

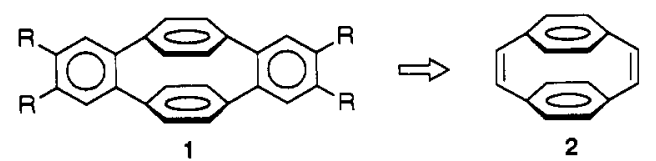

Several synthetic strategies toward benzoannelated [2.2]-

\footnotetext{
†Universitãt Hamburg. New Address: Institut für Organische Chemie der Universität Göttingen, Gustav Tammannstr. 2, D-3400 Göttingen, (West) Germany.

Universität Freiburg.

Universităt Basel.

I Hebrew University, Jerusalem.

(1) (a) Cannon, R. D. Electron Transfer Reactions; Butterworth: London, 1981. (b) Taube, H. Angew. Chem. 1984, 96, 315; Angew. Chem., Int. Ed. Engl. 1984, 23, 329.

(2) (a) Wegner, G. Angew. Chem. 1981, 93, 352; Angew. Chem., Int. Ed. Engl. 1981, 20, 348. (b) Hanack, M. Nachr. Chem., Tech. Lab. 1980, 28,
} 632 .

$0002-7863 / 93 / 1515-3511 \$ 04.00 / 0$ paracyclophanes have been explored. With one exception, ${ }^{3}$ a [2.2] paracyclophane derivative was chosen as the starting material with subsequent arene annelation onto the ethano bridges, thus forming the desired benzoannelated [2.2]paracyclophane structure 1. At first sight a $[4+2]$ cycloaddition of dienes to the readily accessible ${ }^{4}[2.2]$ paracyclophane-1,9-diene $(2)^{5}$ would seem the most straightforward approach to such skeletons. Diene 2, however, failed to react with butadiene, ${ }^{6}$ substituted butadienes, and 5,5-dimethoxy-1,2,3,4-tetrachlorocyclopentadiene. ${ }^{7}$ The first syntheses ${ }^{8}$ of diarene annelated [2.2] paracyclophanes were achieved via intermediates obtained by intermolecular trapping of in situ generated 1,2-benzo[2.2] paracyclophane-9-yne with dienes. ${ }^{9,10}$ A Diels-Alder addition of propargyl aldehyde to 1-vinyl- and 1,9(10)-divinyl[2.2]paracyclophanes afforded another approach to compounds of type $1 .^{4}$

Recently, we developed a general method for annelating sixmembered carbocycles onto 1,2-dibromocycloalkenes ${ }^{11}$ by Hecktype ${ }^{12}$ alkenylation and subsequent cyclization/dehydrogenation of the resulting $(E, Z, E)-1,3,5$-trienes.

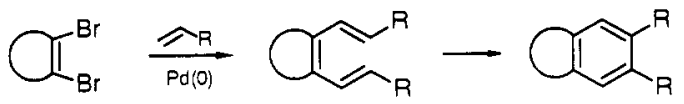

Preliminary studies ${ }^{13}$ had previously established that this protocol is applicable to vicinal dibromoalkenes derived from

(3) Jacobson, N.; Boekelheide, V. Angew. Chem. 1978, 90, 49-50; Angew. Chem., Int. Ed. Engl. 1978, 17, 46-47.

(4) Stöbbe, M.; Reiser, O.; Näder, R.; de Meijere, A. Chem. Ber. 1987, $120,1667$.

(5) Dewhirst, K. C.; Cram, D. J. J. Am. Chem. Soc. 1958, 80, 3115.

(6) (a) Hopf, H.; Psiorz, M. Chem. Ber. 1986, 119, 1836. (b) Psiorz, M. Dissertation, Universität Braunschweig, Braunschweig, Germany, 1983.

(7) Dimethyl tetrazine-3,6-dicarboxylate cleanly undergoes Diels-Alder reactions with 2 in good yields: König, B. Dissertation, Universität Hamburg, Hamburg, Germany, 1991.

(8) Chan, C. W.; Wong, H. N. C. J. Am. Chem. Soc. 1985, 107, 47904791 .

(9) Chan, C. W.; Wong, H. N. C. J. Am. Chem. Soc. 1988, 110, 462-469.

(10) de Meijere, A.; Heinze, J.; Meerholz, K.; Reiser, O.; König, B. Angew. Chem. 1990, 102, 1443-1444; Angew. Chem., Int. Ed. Engl. 1990, 29, 14181419.

(11) Lansky, A.; Reiser, O.; de Meijere, A. Synlett 1990, I, 405.

(12) Heck, R. F. Org. React. (NY) 1983, $27,1$.

(13) Reiser, O.; Reichow, S.; de Meijere, A. Angew. Chem. 1987, 99, 1285 1286; Angew. Chem., Int. Ed. Engl. 1987, 26, 1277-1278. 
Scheme I

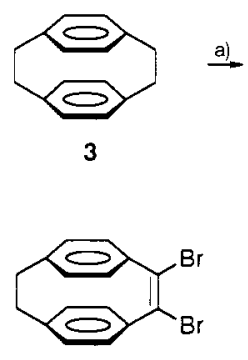

5

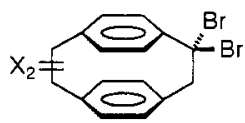

4a $X=H$

4b $X=B r$

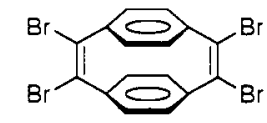

6 (a) $\mathrm{Br}_{2}, \mathrm{CCl}_{4}, \Delta$. (b) $\mathrm{KO} \mathrm{Bu}^{\mathrm{Bu}}, \mathrm{TBME}$, room temperature. (c) $\mathrm{Br}_{2}$, $\mathrm{CHCl}_{3}, \Delta$. (d) $\mathrm{KO}^{\prime} \mathrm{Bu}$, TBME, room temperature.

[2.2] paracyclophane. In this paper we report on the full utility of this strategy as an efficient entry to a wide variety of substituted dibenzo[2.2]paracyclophanedienes of type 1 and on our studies of their electronic properties.

\section{Results and Discussion}

Preparation of Benzoannelated [2.2]Paracyclophanes. 1,2Dibromo[2.2]paracyclophan-1-ene (5) and 1,2,9,10-tetrabromo[2.2] paracyclophane-1,9-diene (6) were envisioned as suitable starting materials for the synthesis of benzoannelated [2.2]paracyclophanes. Hopf and Psiorz ${ }^{6 a}$ first synthesized 5 by monobromination of [2.2]paracyclophane (3) followed by a sequence of dehydrobromination, bromination, and dehydrobromination steps. In our hands, however, it proved to be difficult to control the initial photobromination on a large scale. Mixtures of monobrominated and polybrominated compounds were always obtained, from which the monobromo derivative could not be separated completely.

The observation that the four-fold photobromination of $\mathbf{3}$ with bromine $^{5}$ affords the geminal 1,1,9,9-and 1,1,10,10-tetrabromides 4b along with considerable amounts $(20-30 \%)$ of the geminal dibromide $4 \mathbf{a}$ led us to the development of an alternate route to both 5 and 6 . In a sequence of dehydrobromination, exhaustive bromination, and dehydrobromination, a mixture of dibromomonoene 5 and tetrabromodiene 6 was obtained, which could easily be separated by crystallization due to their vastly different solubilities in chloroform (Scheme I).

Compounds 5 and 6 , thus accessible in multigram quantities, were subjected to palladium-catalyzed coupling reactions with various alkenes $\mathbf{7 a - j}$. According to the protocol originally suggested by Jeffery, ${ }^{14}$ which calls for addition of a phase-transfer catalyst, ${ }^{15}$ the two-and four-fold coupling products were obtained in respectable yields in most cases (Scheme II and Table I). Propene and ethylene gave poor results under the conditions employed. While no product was obtained from 5 with propene, 6 with ethene gave the four-fold adduct $9 a$, which was converted to 1 a (overall yield $14 \%$ ). 1a could be obtained more conveniently and in higher overall yield $(21 \%)$ by using vinyltrimethylsilane as an ethene equivalent in the coupling step. Under the basic conditions employed, the trimethylsilyl groups were cleaved off in situ to a large extent ( $>95 \%$ according to ${ }^{1} \mathrm{H}$ NMR).

Consistently better results were obtained by using alkenes with electron-withdrawing substituents (entries $1-3,7-13$ in Table I). Unfortunately, the bis-triene 9d derived from coupling with acrolein proved to be rather unstable, and all attempts to realize further conversion to the tetraaldehyde 1d failed. Methyl acrylate (entries 1,8) and various substituted styrenes (entries 2, 3, 9-13), however, cleanly and stereoselectively gave the corresponding $(E, Z, E)$-trienes 11 and bis-trienes 9, which could be isolated without any apparent isomerization or decomposition. Subsequent

(14) Jeffery, T. Tetrahedron Lett. 1985, 26, 2667-2670.

(15) Contrary to the procedure in ref 14 , we used the cheaper tetrabutylammonium bromide instead of the chloride with good results.
Scheme II. (For Designation of Substituents R and Yields, See Table I)

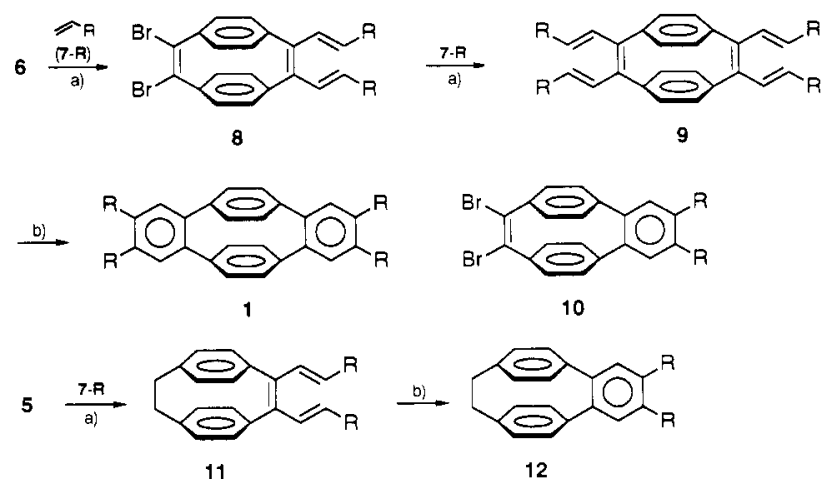

(a) $\mathrm{Pd}(\mathrm{OAc})_{2}, \mathrm{Bu}_{4} \mathrm{NBr}, \mathrm{K}_{2} \mathrm{CO}_{3}$ or $\mathrm{NaHCO}_{3}, \mathrm{DMF}$. (b) $\mathrm{DDQ}$ (or S), xylene, $\Delta$.

\section{Scheme III}

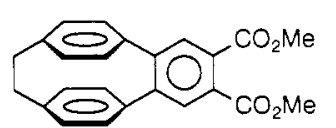

$12 \mathrm{e}$

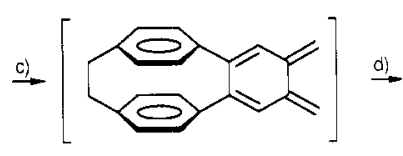

14

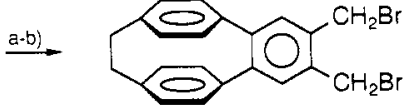

13

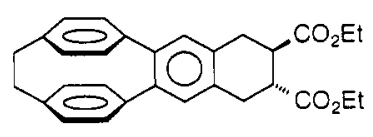

15 (a) $\mathrm{LiAlH}_{4}, \mathrm{THF}, \Delta$. (b) $\mathrm{PBr}_{3}, \mathrm{C}_{6} \mathrm{H}_{6}$, room temperature. (c) $\mathrm{Zn}$, $\mathrm{THF},()))$. (d) Diethyl fumarate, room temperature.

thermal $6 \pi$-electrocyclization of products 9 and 11 in the presence of sulfur or DDQ resulted in the formation of dibenzoannelated [2.2] paracyclophanes 1 and monobenzoannelated analogues 12.

Interestingly, no monoalkenylated products were isolated. Competition experiments in a recent study ${ }^{11}$ have revealed that the second coupling step in a palladium-catalyzed alkenylation of 1,2-dibromocyclohexene is about 50 times faster than the first step yielding 1-bromo-1,3-dienes. In agreement with these findings, the only intermediates we observed in the four-fold coupling of 6 were the two-fold alkenylated adducts 8 , which could be cyclized to give monobenzoannelated dibromo[2.2]paracyclophanes 10, as established for compounds $8 \mathrm{e}$ and $\mathbf{8 f}$.

This ring annelation method leads to 1,2-disubstituted arenes, which offer themselves for further elaboration, especially toward [2.2] paracyclophane derivatives with extended mutually orthogonal polycyclic $\pi$-systems.

A particularly attractive intermediate for further ring annelation appeared to be the $o$-xylylene annelated paracyclophane 14, for which 13 ought to be an ideal precursor, since transformation of $o$-bis(bromomethyl)benzenes to $o$-xylylenes is well precedented. ${ }^{16,17}$

Reduction of the diester $12 \mathrm{e}$ with lithium aluminum hydride to the bis-benzyl alcohol and subsequent nucleophilic substitution with phosphorus tribromide cleanly gave 13 in $70 \%$ overall yield. Attempts to isolate a tricarbonyliron( 0 complex of 14 by treating 13 with enneacarbonyldiiron $(0)^{18}$ failed. By reacting 13 with zinc under ultrasound activation, ${ }^{19}$ however, 14 could be generated in situ and trapped with diethyl fumarate to give the $[4+2]$ cycloadduct 15 in $70 \%$ yield (Scheme III).

(16) Cf. (a) Johnson, B. F. G.; Lewis, J.; Thompson, D. J. Tetrahedron Lett. 1974, 3789. (b) Roth, W. R.; Main, J. D. Tetrahedron Lett. 1967, 2053. (17) Cf. (a) Alder, K.; Fremery, M. Tetrahedron 1961, 14, 190. (b) Han, B. H.; Boudjouk, P. J. Org. Chem. 1982, 47, 751.

(18) Cf. Liu, L.; Yang, B.; Katz, T. J.; Pointdexter, M. K. J. Org. Chem. 1991, 56, 3769-3775 and references cited therein.

(19) Hopf, H. Naturwissenschaften 1983, 70, 349. 
Table I. Palladium-Catalyzed Coupling Reactions of 5 and 6 with Various Alkenes 7 and Subsequent Cyclization/Dehydrogenation of the Resulting $(E, Z, E)-1,3,5$-Trienes 9 and 11

\begin{tabular}{|c|c|c|c|c|c|c|c|c|c|}
\hline entry & starting material & 7 & alkene $\mathbf{R}$ & temp, ${ }^{\circ} \mathrm{C}$ (time) & product triene & yield, \% & oxidant & product arene & yield, $\%$ \\
\hline 1 & 5 & e & $\mathrm{CO}_{2} \mathrm{Me}$ & $50(12 \mathrm{~h})$ & 11e & 44 & DDQ & $12 e$ & 45 \\
\hline 2 & 5 & $\mathbf{f}$ & $\mathrm{C}_{6} \mathrm{H}_{5}$ & $100(3 d)$ & $11 f$ & 58 & DDQ & $12 \mathrm{f}$ & 53 \\
\hline 3 & 5 & $\mathbf{i}$ & $p-\mathrm{CO}_{2} \mathrm{Me}-\mathrm{C}_{6} \mathrm{H}_{4}$ & 70 (1d) & $11 \mathbf{i}$ & 57 & S & $12 \mathbf{i}$ & 65 \\
\hline 4 & 5 & c & $\mathrm{CH}_{3}$ & $100(2 d)$ & $11 \mathrm{c}$ & 0 & & & \\
\hline 5 & 6 & $\mathbf{a}$ & $\mathrm{H}$ & $100(2 d)$ & $9 \mathbf{a}$ & 24 & $\mathbf{S}$ & $1 \mathbf{a}$ & 58 \\
\hline 6 & 6 & b & $\mathrm{SiMe}_{3}$ & $40(5 d)$ & $9 \mathbf{b}$ & $a$ & $\mathrm{~s}$ & $1 \mathrm{a}$ & $21^{b}$ \\
\hline 7 & 6 & d & $\mathrm{CHO}$ & $40(2 d)$ & 9d & 38 & $\mathbf{S}$ & 1d & 0 \\
\hline 8 & 6 & e & $\mathrm{CO}_{2} \mathrm{Me}$ & $70(12 \mathrm{~h})$ & $9 e$ & 48 & $\mathbf{S}$ & $1 \mathrm{e}$ & 43 \\
\hline 9 & 6 & f & $\mathrm{C}_{6} \mathrm{H}_{5}$ & $100(3 d)$ & 9f & 55 & $\mathrm{~s}$ & 1f & 50 \\
\hline 10 & 6 & g & $p-\mathrm{F}-\mathrm{C}_{6} \mathrm{H}_{4}$ & $70(2 d)$ & $9 \mathrm{~g}$ & $a$ & $\mathbf{S}$ & $1 \mathrm{~g}$ & $20^{b}$ \\
\hline 11 & 6 & $\mathbf{h}$ & $p^{t} \mathrm{Bu}-\mathrm{C}_{6} \mathrm{H}_{4}$ & $100(2 d)$ & $9 \mathrm{~b}$ & 55 & $\mathbf{S}$ & lh & 45 \\
\hline 12 & 6 & $\mathbf{i}$ & $p-\mathrm{CO}_{2} \mathrm{Me}-\mathrm{C}_{6} \mathrm{H}_{4}$ & $70(36 \mathrm{~h})$ & $9 i$ & 58 & $\mathbf{S}$ & $\mathbf{j i}$ & 80 \\
\hline 13 & 6 & $\mathbf{j}$ & $p-\mathrm{C}_{6} \mathrm{H}_{5}-\mathrm{C}_{6} \mathrm{H}_{4}$ & $100(4 d)$ & $9 j$ & 15 & DDQ & $\mathbf{1 j}$ & 31 \\
\hline
\end{tabular}

${ }^{a}$ Not isolated. ${ }^{b}$ Yield based on 6.

Scheme IV

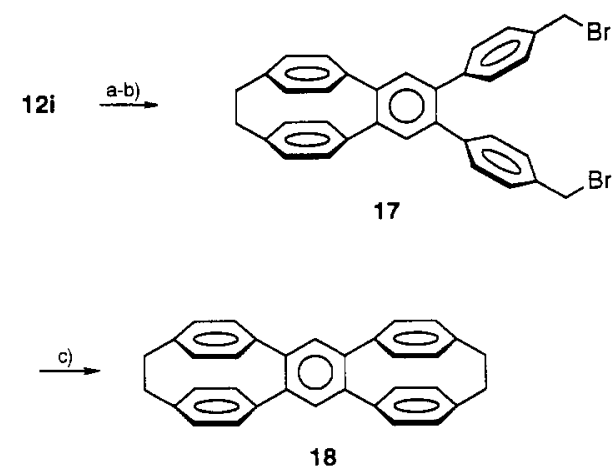

(a) $\mathrm{LiAlH}_{4}, \mathrm{THF}, \Delta$. (b) $\mathrm{PBr}_{3}, \mathrm{C}_{6} \mathrm{H}_{6}$, room temperature. (c) $\mathrm{PhLi}$, $\mathrm{Et}_{2} \mathrm{O}$.

Since coupling of 6 with styrenes and cyclization/oxidation provides an access to 0 -terphenyl annelated [2.2] paracyclophanes 1f $-\mathbf{j}$, the photocyclization ${ }^{18}$ of these to terphenylene annelated derivatives was tested. Irradiation of $1 \mathrm{f}$ at $254 \mathrm{~nm}$ in the presence of iodine caused the disappearance of the starting material; the isolated product, however, proved to be so sparsely soluble that it could not be sufficiently characterized. The tetra-tert-butylsubstituted derivative $\mathbf{1 6}$, obtained from photocyclization of $\mathbf{1 h}$ in $66 \%$ isolated yield, has a better solubility and could be characterized by its ${ }^{1} \mathrm{H}$ NMR spectrum and by cyclic voltammetry (see below).

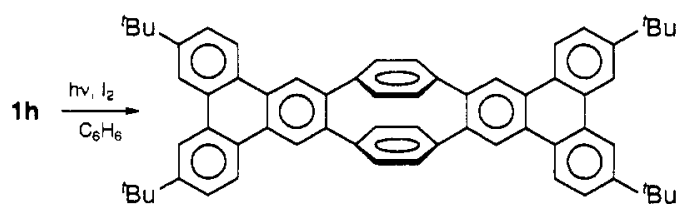

16

The minimal solubility of $\mathbf{1 6}$ in organic solvents prevented, however, recording of a ${ }^{13} \mathrm{C}$ NMR spectrum. For unknown reasons, a mass spectrum of 16 could not be obtained by electron impact, field desorption, and fast atom bombardment ionization techniques.

Finally, the first benzobis[2.2] paracyclophane 18 was synthesized starting from the di-p-carbomethoxyphenyl derivative $12 \mathrm{i}$ (Scheme IV). Reduction of $12 \mathrm{i}$ with $\mathrm{LiAlH}_{4}$, and conversion of the resulting diol with phosphorus tribromide, gave the bisbromomethyl derivative 17. Upon treatment of 17 with phenyllithium in diethyl ether, 18 was isolated in $8 \%$ yield, along with dehalogenated and polymeric materials.

Despite this low yield, $\mathbf{1 8}$ could be completely purified and its constitution was unambiguously verified by its high-resolution mass and ${ }^{1} \mathrm{H}$ NMR spectrum. Prominent in the latter spectrum is an $\mathrm{AA}^{\prime} \mathrm{BB}^{\prime}$ system at $6.64 \mathrm{ppm}$, which is characteristic for [2.2] paracyclophanes. ${ }^{19}$ The signal for the two protons of the doubly annelated benzene appears as a singlet at $7.79 \mathrm{ppm}$, while the eight protons of the ethano bridges are represented by another singlet at $3.13 \mathrm{ppm}$.

Spectroscopic and Cyclic Voltammetric Studies of Redox Processes in Benzoannelated [2.2] Paracyclophanes. NMR studies were carried out on anions derived from the parent compound 1a, the previous reported diphenyl derivative $19,{ }^{4}$ and the tetraphenyl derivative 1f. These compounds were each treated with lithium, sodium, or potassium in THF- $d_{8}$ at $-78^{\circ} \mathrm{C}$. In all cases, deeply colored solutions were obtained, which were periodically analyzed by ${ }^{1} \mathrm{H}$ and ${ }^{13} \mathrm{CNMR}$ spectroscopy in a temperature range between 0 and $-80^{\circ} \mathrm{C}$.

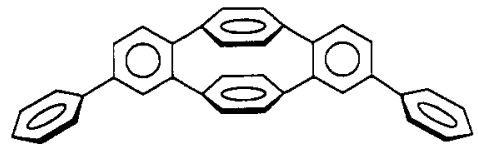

19

At no point were NMR signals observed for the reduction products of the unsubstituted dibenzo[2.2] paracyclophanediene 1a, regardless of the alkali metal employed. This failure indicates that no diamagnetic species, in particular no stable singlet dianion, was formed from 1a. This complements the ESR studies of 1a, ${ }^{20}$ in which only a radical monoanion, but no paramagnetic dianion, was observed.
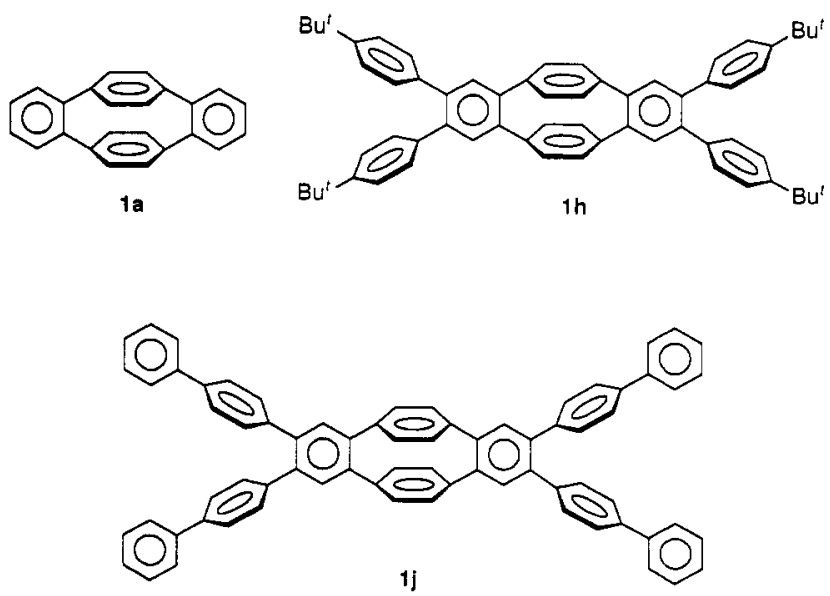

In contrast, after 2-weeks exposure to sodium or potassium mirror at $-78^{\circ} \mathrm{C}$, the solutions of $1 \mathrm{f}$ and 19 showed NMR signals; these were, however, too broad to be reliably analyzed. As proved

(20) Gerson, F.; Martin, W. B., Jr.; Wong, H. N. C.; Chan, C. W. Helv. Chim. Acta 1987, 70, 79. 
Table II. Reversible Reduction Potentials $E^{\circ}$ (V) of Some Arene Annelated [2.2]Paracyclophanedienes and Related Model Compounds as Measured by Cyclic Voltammetry ${ }^{a}$

\begin{tabular}{|c|c|c|c|c|c|c|c|c|}
\hline & $1 \mathrm{a}$ & Ih & $\mathbf{1 j}$ & 16 & 19 & 20 & 21 & 22 \\
\hline $\begin{array}{l}E_{1 / 2^{(1)}} \\
E_{1 / 2^{(2)}} \\
E_{1 / 2^{(3)}} \\
E_{1 / 2^{(4)}} \\
E_{1 / 2^{(5)}} \\
E_{1 / 2}{ }^{(6)}\end{array}$ & $\begin{array}{l}-2.68 \\
-2.98\end{array}$ & $\begin{array}{l}-2.54 \\
-2.61 \\
-2.80 \\
-2.89\end{array}$ & $\begin{array}{l}-2.43^{b} \\
-3.08 \\
-3.18\end{array}$ & $\begin{array}{l}-2.41 \\
-2.50 \\
-2.75 \\
-3.02\end{array}$ & $\begin{array}{l}-2.54 \\
-2.60 \\
-2.91 \\
-3.21\end{array}$ & $\begin{array}{l}-2.68 \\
-3.18\end{array}$ & $\begin{array}{l}-2.62 \\
-2.72\end{array}$ & $\begin{array}{l}-2.42 \\
-2.97\end{array}$ \\
\hline
\end{tabular}

${ }^{a}$ Recorded with a Pt electrode for $10^{-4}$ to $10^{-5} \mathrm{M}$ solutions in a dimethylamine/THF (1:1) mixture. All potentials were determined as the average of the cathodic and the anodic peak potentials and are expressed in $\mathrm{V}$ vs $\mathrm{Ag} / \mathrm{AgCl}$ (calibration with $\left[\mathrm{Cp}_{2} \mathrm{Co}\right]^{+} / \mathrm{Cp}_{2} \mathrm{Co}$ ). The temperature was kept between 233 and $198 \mathrm{~K} .{ }^{b}$ This is a four-electron reduction step.

by ESR spectroscopy, both 19 and 1 form the triplet dianions with one electron located in each of the annelated biphenyl and $o$-terphenyl systems, respectively; ${ }^{21}$ it might be concluded that the observed NMR signals are derived from the corresponding diamagnetic singlet dianions. An analysis of the temperaturedependent ESR signals pointed to the triplet being the ground state of these dianions with a singlet only about $2 \mathrm{kj} / \mathrm{mol}$ higher. This finding is consistent with the observation of such singlet dianions by NMR spectroscopy, as the Boltzmann distribution would lead to a detectable fraction of them in equilibrium with the triplet species and the presence of the latter ones in solution would cause the observed line broadening.

After prolonged contact of $\mathbf{1 f}$ and $\mathbf{1 9}$ with potassium metal, the NMR signals disappeared, indicating the formation of paramagnetic trianions which were also observed by ESR/ ENDOR spectroscopy. ${ }^{21}$ Finally, the anion solutions were quenched with dioxygen. In all cases the starting material was recovered without any trace of decomposition, ensuring that the observed species were indeed reversibly formed anions of benzoannelated [2.2] paracyclophanes.

The cyclic voltammetric studies of some derivatives of 1 (Table II) complement the results of our ESR and NMR measurements. In all cases, the observed reduction steps are reversible, even for the highly charged species of $\mathbf{1 j}$ (vide infra).

The first reduction step of $1 \mathrm{a}$ occurs at $E_{1 / 2}(1)=-2.68 \mathrm{~V}$ vs SCE, which is a substantially less negative potential than that of [2.2] paracyclophane $\left(E_{1 / 2}{ }^{(1)}=-3.00 \mathrm{~V}\right.$ vs $\left.\operatorname{SCE}^{22}\right)$, as the uptake of an electron becomes easier upon extension of the $\pi$-system vs SCE, albeit with mutually orthogonal subunits. Consequently, the $E_{1 / 2}{ }^{(1)}$ value of $1 \mathrm{a}$ is almost equal to that of $o$-terphenyl (21), in which the three rings are also almost orthogonal to each other. ${ }^{23}$ 1a may be regarded as a sterically constrained o-terphenyl derivative which is bridged in the para position of its terminal phenyl units by another orthogonal benzene ring.

Although a dianion of 1 a could not be observed either by ESR or NMR spectroscopy, the cyclic voltammogram revealed a second reduction step at $E_{1 / 2}{ }^{(2)}=-2.98 \mathrm{~V}$. This value is now significantly more negative than the corresponding potential of $o$-terphenyl (21) with $E_{1 / 2}{ }^{(2)}=-2.72 \mathrm{~V}$, which demonstrates a strong Coulombic repulsion in 1 a due to the strong $\pi-\pi$ interaction between the parallel and face to face oriented benzene rings at a distance of only $314 \mathrm{pm} .{ }^{24}$ This $\pi-\pi$ interaction is weaker in 21 , and consequently, its second reduction step is separated from the first by only $100 \mathrm{mV}$.

The tetrakis ( $p$-tert-butylphenyl) derivative $1 \mathrm{~h}$ and the diphenyl derivative 19 of $1 \mathrm{a}$, as well as the bis-triphenylene annelated compound 16, could be reduced to their tetraanions. The first two reduction potentials, $E_{1 / 2}{ }^{(1)}$ and $E_{1 / 2}{ }^{(2)}$, lie in the same range as the $E_{1 / 2}{ }^{(1)}$ values of the corresponding subunits $o$-terphenyl (21), biphenyl (20), and triphenylene (22), respectively. This

(21) For a detailed discussion of this ESR study see: de Meijere, A.; Gerson, F.; König, B.; Reiser, O.; Wellauer, T. J. Am. Chem. Soc. 1990, 112, 6827. (22) Jund, R.; Lemoine, P.; Gross, M. Angew. Chem. 1982, 94, 312; Angew. Chem., Int. Ed. Engl. 1982, 21, 305.

(23) Meerholz, K.; Heinze, J. J. Am. Chem. Soc. 1989, 111, 2325-2326.

(24) Wong, H. N. C.; Chan, C. W.; Mak, T. C. W. Acta Crystallogr. 1986, C42, 703-705. fact supports the notion that these subunits are reduced separately and almost independently of each other, as previously found in the ESR/ENDOR studies for $1 \mathrm{~h}$ and 19.21 Due to the rather slight interactions between the two subunits in $1 \mathrm{~h}, 16$, and 19 , the potentials, $E_{1 / 2}{ }^{(1)}$ and $E_{1 / 2}{ }^{(2)}$, of the three compounds are almost degenerate.

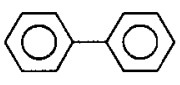

20

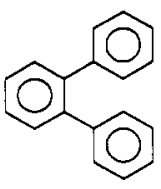

21

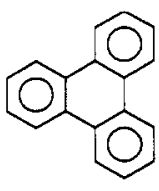

22
The third reduction potential of $1 \mathbf{h}, E_{1 / 2}{ }^{(3)}=-2.80 \mathrm{~V}$, is considerably less negative than the $E_{1 / 2}\left({ }^{(1)}\right.$ value of $-3.00 \mathrm{~V}$ for [2.2] paracyclophane (3), given the fact that both annelated $o$-terphenyl units are already charged. Nevertheless, the ESR spectrum of the radical trianion of $1 \mathrm{~h}$ proved unambiguously that the third electron is accommodated in the central paracyclophane subunit. In this way, the distances between the three charges are maximized. Similar to the case of $\mathbf{1 h}$, the third electron in 19 should be located in the central paracyclophane unit, all the more as the second reduction potential of $20, E_{1 / 2}{ }^{(2)}$ $=-3.18 \mathrm{~V}$, is markedly more negative than the corresponding value of $-2.72 \mathrm{~V}$ for 21 . Indeed, the third reduction potential of $19, E_{1 / 2}{ }^{(3)}=-2.91 \mathrm{~V}$, is rather close to that of $1 \mathrm{~h}(-2.80 \mathrm{~V})$, and the location of the third electron in the paracyclophane subunit was confirmed by the ESR spectrum of the radical trianion of 19. ${ }^{21}$ On the other hand, the fourth reduction potential of 19 , $E_{1 / 2}{ }^{(4)}=-3.21 \mathrm{~V}$, is distinctly more negative then the corresponding value of $-2.89 \mathrm{~V}$ for $1 \mathrm{~h}$; this difference parallels that in the second reduction potentials, $E_{1 / 2}{ }^{(2)}$, of the respective lateral subunits $20(-3.18 \mathrm{~V})$ and $21(-2.72 \mathrm{~V})$. It must, therefore, be assumed that the fourth electron in $1 \mathrm{~h}$ and 19 is mainly accommodated in one of these subunits, a conclusion which is difficult to confirm by ESR spectroscopy.

No ESR evidence is available for the paramagnetic anions of 16 , as the spectra observed upon alkali-metal reduction of this compound were hardly interpretable, presumably due to the occurrence of two or more different species. As mentioned above, the first two reduction steps of $\mathbf{1 6}$ (see Figure 1) at $E_{1 / 2}{ }^{(1)}=-2.41$ and $E_{1 / 2}(2)=-2.50 \mathrm{~V}$ compare favorably with the value $E_{1 / 2}{ }^{(1)}$ $=-2.42 \mathrm{~V}$ for 22. This comparison indicates that the two steps involve a subsequent uptake of electrons into each of the triphenylene subunits of 16 . It is less certain to which subunit of 16 the admission of the third and fourth electrons should be assigned. The finding that the third reduction potential of 16 , $E_{1 / 2}{ }^{(3)}=-2.75 \mathrm{~V}$, is close to the corresponding value of $1 \mathrm{~h}(-2.80$ V) suggests that, here too, the central paracyclophane subunit represents the site of the third electron in the radical trianion of 16. The fourth electron, on the other hand, may enter the lateral triphenylene subunits, as the $E_{1 / 2}{ }^{(4)}$ value of $-3.02 \mathrm{~V}$ for 16 is similar to the second reduction potential, $E_{1 / 2}(2)$, of $22(-2.97 \mathrm{~V})$.

The tetrakisbiphenyl-substituted derivative $\mathbf{1 j}$ can even be reduced to its hexaanion. The first four reduction steps occur all 


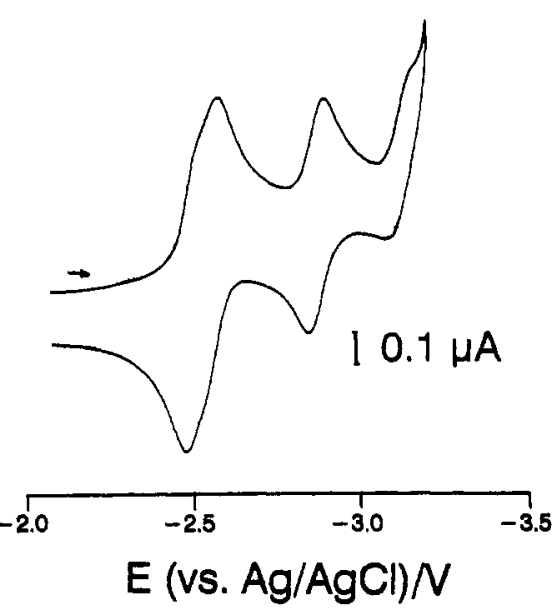

Figure 1. Cyclic voltammogram for the reduction of 16 in DMA/THF (1:1), $0.1 \mathrm{M} \mathrm{TBABr}$, scan rate $100 \mathrm{mV} \mathrm{s}^{-1}, T=213 \mathrm{~K}$.

in the potential range between -2.38 and $-2.48 \mathrm{~V}$. As the lateral pentaphenyl units in $1 \mathbf{j}$ are even more extended $\pi$-systems than $o$-terphenyl (21), its first two reduction potentials may be expected to be almost degenerate; therefore, a two-electron reduction step for each of these subunits is observed. Furthermore, it is assumed that the fifth excess charge is stored in the central paracyclophane subunit, although the small difference of $0.1 \mathrm{~V}$ between $E_{1 / 2}{ }^{(s)}$ and $E_{1 / 2}{ }^{(6)}$ may be taken as an indication that the fifth and the sixth electron are actually located in the lateral pentaphenyl subunits.

\section{Conclusions}

The results of the ESR, NMR, and cyclovoltammetric studies provide affirmative answers to both questions put forward in the introduction. On the one hand, the ESR/ENDOR studies of the radical anions, triplet dianions, and radical trianions of $\mathbf{1 h}, \mathbf{1 j}$, and 19 indicate that the $\pi$-subsystems in these bis-annelated [2.2]paracyclophanes are sufficiently isolated to take up electrons one by one in consecutive redox steps. ${ }^{21}$ On the other hand, cyclic voltammograms of $1 \mathrm{~h}, 1 \mathrm{j}$, and 16 point to a substantial interaction between their "isolated" $\pi$-systems, as the reduction potentials attributed to these systems are considerably less negative than those of the corresponding parent hydrocarbons 1a, 20, 21, and 22, which are subunits in $1 \mathrm{~h}, \mathbf{1 j}$, and 16. Benzoannelated [2.2]paracyclophanes are therefore highly efficient electron acceptors. The unusual geometry of their carbon framework allows reversible acceptance of four to six electrons, thus making especially $1 \mathbf{j}$ an attractive model for a charge storage system.

\section{Experimental Section}

General Methods. Melting points were determined on an electrothermal melting point apparatus and are uncorrected. Infrared spectra were recorded by Perkin Elmer 297 and 399 spectrophotometers. ${ }^{1} \mathrm{H}$ NMR spectra were taken on Bruker AM-250 (250 MHz), WH-270 (270 MHz), and WM-400 (400 MHz) spectrometers at ambient temperature. Data are reported as follows: Chemical shifts in ppm from internal tetramethylsilane on the $\delta$ scale; multiplicity $(b=$ broad, $s=$ singlet, $d=$ doublet, $\mathrm{t}=$ triplet, $q=$ quartet, and $\mathrm{m}=$ multiplet $)$, integration, coupling constant $(\mathrm{Hz})$, and assignment. Chemical shifts are given in ppm on the $\delta$ scale, with the solvent resonance employed as the internal standard (chloroform at $7.24 \mathrm{ppm}$, benzene- $d_{5}$ at $7.15 \mathrm{ppm}$, and DMSO- $d_{5}$ at 2.49 ppm). ${ }^{13} \mathrm{C}$ NMR were recorded on Bruker AM-250 (62 MHz), WM$270(67 \mathrm{MHz})$, and WM-400 (100 MHz) spectrometers at ambient temperature; $\delta=77.0 \mathrm{ppm}$ for $\mathrm{CDCl}_{3}$. Ultraviolet spectra were recorded on a Perkin-Elmer-Hitachi spectrometer. Mass spectrometry analyses were performed on a Varian MAT CH-7 spectrometer. Combustion analyses were carried out by Microanalytical Laboratory, University of Hamburg, and Beller Microanalytical Laboratory, Göttingen. Analytical thin-layer chromatography (TLC) was performed using Merck silica gel $60-F_{254}$ on aluminum foil. Liquid chromatography was performed using a forced flow (flash chromatography) of the indicated solvent system on Merck silica gel 60 (70-230 mesh). When necessary, solvents and reagents were purified prior to use by standard laboratory procedures. ${ }^{25}$ All voltammetric measurements were performed with dimethylamine/THF solutions (1:1 mixture) and carried out with a PAR potentiostat Model 173 and a PAR universal programmer Model 175. Cyclic voltammograms were recorded with a Model HP 7004B X-Y instrument. A threeelectrode configuration was employed throughout. Details are described elsewhere. ${ }^{26}$ Experimental conditions for the ESR/ENDOR studies were indicated previously. ${ }^{21}$

1,2,9,10-Tetrabromo[2.2]paracyclophane-1,9-diene (6). A solution of $14.3 \mathrm{~g}(89.5 \mathrm{mmol})$ of bromine in $100 \mathrm{~mL}$ of $\mathrm{CHCl}_{3}$ was added dropwise to a solution of $16.2 \mathrm{~g}$ (44 mmol) of 1,9(10)-dibromo[2.2] paracyclophane1,9 -diene 5 in $150 \mathrm{~mL}$ of $\mathrm{CHCl}_{3}$ while refluxing for $3 \mathrm{~h}$. The precipitate was collected by filtration, the filtrate was concentrated to a volume of $30 \mathrm{~mL}, 100 \mathrm{~mL}$ of hexane was added, and the precipitated solid was again removed by filtration. The combined residues were dried in vacuo yielding $21.7 \mathrm{~g}(71 \%)$ of $1,1,2,9,9(10), 10$-hexabromo[2.2] paracyclophane. A small sample was recrystallized from $\mathrm{CCl}_{4}$ for analytical characterization. ${ }^{1} \mathrm{H}$ NMR (270 MHz, $\left.\mathrm{CDCl}_{3}\right): \delta 5.97[\mathrm{~s}, \mathrm{H}-2,9,(10)], 7.03(\mathrm{~m}, 8 \mathrm{H}$, $\mathrm{H}$-aromatic). MS (70 eV) $m / z(\%): 680 / 682 / 684\left(2 / 3 / 2, \mathrm{M}^{+}\right), 597 /$ $599 / 601 / 603 / 605 / 607\left(2 / 7 / 14 / 13 / 7 / 1, \mathrm{M}^{+}-\mathrm{Br}\right), 518 / 520 / 522 / 524 /$ $526\left(7 / 28 / 40 / 26 / 7, \mathrm{M}^{+}-2 \mathrm{Br}\right), 439 / 441 / 443 / 445\left(8 / 24 / 22 / 9, \mathrm{M}^{+}\right.$ - $3 \mathrm{Br}), 360 / 362 / 364\left(10 / 20 / 10, \mathrm{M}^{+}-4 \mathrm{Br}\right), 281 / 283\left(16 / 15, \mathrm{M}^{+}\right.$ $5 \mathrm{Br}), 202\left(100, \mathrm{M}^{+}-6 \mathrm{Br}\right)$. Anal. Calcd for $\mathrm{C}_{16} \mathrm{H}_{10} \mathrm{Br}_{6}: \mathrm{C}, 28.19 ; \mathrm{H}$, $1.48 ; \mathrm{Br}, 70.33$. Found: $\mathrm{C}, 27.97 ; \mathrm{H}, 1.43 ; \mathrm{Br}, 70.10$.

A suspension of $21.7 \mathrm{~g}(31.8 \mathrm{mmol})$ of $1,1,2,9,9(10), 10$-hexabromo[2.2]paracyclophane and $14.0 \mathrm{~g}(125 \mathrm{mmol})$ of potassium tert-butoxide $\left(\mathrm{KO} \mathrm{O}^{\circ} \mathrm{Bu}\right.$ ) in $200 \mathrm{~mL}$ of methyl tert-butyl ether (TBME) was stirred at room temperature for $12 \mathrm{~h}$. The reaction mixture was evaporated to dryness and the solid residue continuously extracted with chloroform for 7 days. The precipitate in the extraction solution was filtered off, washed with $50 \mathrm{~mL}$ of cold chloroform, and dried in vacuo yielding $11.6 \mathrm{~g}(70 \%)$ of 6, as tiny yellow crystals. 'H NMR $\left(270 \mathrm{MHz}, \mathrm{CDCl}_{3}\right): \delta 6.74(\mathrm{~s}$, $\mathrm{H}$-aromatic). ${ }^{1} \mathrm{H} \mathrm{NMR}\left(270 \mathrm{MHz}, \mathrm{C}_{6} \mathrm{D}_{6}\right): \delta 6.09$ (s). $\mathrm{MS}(70 \mathrm{eV}) \mathrm{m} / \mathrm{z}$ (\%): $516 / 518 / 520 / 522 / 524\left(3 / 6 / 13 / 15 / 9, M^{+}\right)$. Anal. Calcd for $\mathrm{C}_{16} \mathrm{H}_{8} \mathrm{Br}_{4}: \mathrm{C}, 36.97 ; \mathrm{H}, 1.55 ; \mathrm{Br}, 61.48$. Found: $\mathrm{C}, 37.22 ; \mathrm{H}, 1.54 ; \mathrm{Br}$, 61.35.

1,2-Dibromo[2.2]paracyclophan-1-ene (5). Bromine $(8.0 \mathrm{~g}, 2.6 \mathrm{~mL}$, $50 \mathrm{mmol}$ ) was added dropwise to a refluxing solution of $10 \mathrm{~g}$ of fractions II $\left(R_{f}=0.22\right)$ and III $\left(R_{f}=0.22\right.$ and 0.09$)$ of the column chromatographic isolation of 1,9(10)-dibromo[2.2] paracyclophane-1,9-diene consisting $^{5}$ of a mixture of 1,9(10)-dibromo[2.2] paracyclophane-1,9-diene, 1-bromo[2.2]paracyclophane-1-ene, and 1,9(10)-dibromo[2.2] paracyclophan-1ene in $150 \mathrm{~mL}$ of $\mathrm{CHCl}_{3}$. The mixture was refluxed until the red color disappeared and then evaporated to dryness. The solid residue was washed with three portions $(100 \mathrm{~mL})$ of petroleum ether $(30 / 40)$ [PE $(30 / 40)]$, dried in vacuo, and suspended in $400 \mathrm{~mL}$ of dry TBME. KO'Bu (11.2 $\mathrm{g}, 100 \mathrm{mmol}$ ) was added, and the brown mixture was stirred for $6 \mathrm{~h}$ at room temperature and evaporated to dryness in vacuo. The residue was continuously extracted with chloroform for 5 days. From the extraction solution was collected by filtration $2.51 \mathrm{~g}(\sim 35 \%)$ of precipitated 6 , and the solution was evaporated to dryness. The residue was recrystallized from heptane, yielding $3.5 \mathrm{~g}(\sim 55 \%)$ of pure $5, \mathrm{mp} 196^{\circ} \mathrm{C}$. The spectroscopic data are identical with those reported. ${ }^{6}$

General Procedure (GP 1) for the Coupling of 5 with Alkenes. A mixture of $1.0 \mathrm{mmol}$ of 5 , the specified amount of the alkene, $5.0 \mathrm{mmol}$ of potassium carbonate $\left(\mathrm{K}_{2} \mathrm{CO}_{3}\right), 2.0 \mathrm{mmol}$ of tetrabutylammonium bromide $\left(\mathrm{Bu}{ }_{4} \mathrm{NBr}\right)$, and $25 \mathrm{mg}(0.11 \mathrm{mmol})$ of palladium acetate $\mathrm{Pd}$ (OAc) $)_{2}$ under nitrogen in $20 \mathrm{~mL}$ of dry dimethylformamide (DMF) was heated with vigorous stirring in a capped Pyrex bottle. At the end of the reaction, $100 \mathrm{~mL}$ of dichloromethane was added, the organic phase was washed with five portions of $50 \mathrm{~mL}$ of water, and the combined aqueous phases were extracted with $50 \mathrm{~mL}$ of dichloromethane. The combined organic phases were dried over magnesium sulfate $\left(\mathrm{MgSO}_{4}\right)$ and evaporated in vacuo. The crude products were chromatographed on silica gel. The obtained trienes were heated for $1 \mathrm{~h}$ in $50 \mathrm{~mL}$ of xylene under reflux; subsequently an equimolar amount of dichlorodicyano- $p$-benzoquinone (DDQ) or sulfur was added, and the mixture was further refluxed for $5 \mathrm{~b}$. The organic phase was diluted with $80 \mathrm{~mL}$ of diethyl ether,

(25) Perrin, D. D.; Armarego, W. L. F.; Perrin, D. R. Purification of Laboratory Chemicals, 2nd ed.; Pergamon Press: New York, 1980.

(26) Hinkelmann, K.; Heinze, J.; Field, H.-T.; Vahrenkamp, H. J. Am. Chem. Soc. 1989, 111, 5078-5090. 
washed twice with $100 \mathrm{~mL}$ of dilute $\mathrm{NaOH}$, and dried over $\mathrm{MgSO}_{4}$. The solvent was removed in vacuo and the residue chromatographed on silica gel.

$4^{\prime}, 5^{\prime}$-Dicarbomethoxy-1,2-benzo[2.2]paracyclophan-1-ene (12e). 5 $(800 \mathrm{mg}, 2.2 \mathrm{mmol})$ and $1.17 \mathrm{~g}(1.25 \mathrm{~mL}, 13.8 \mathrm{mmol})$ of methyl acrylate were reacted following GP 1 for $12 \mathrm{~h}$ at $50^{\circ} \mathrm{C}$. Column chromatography on $50 \mathrm{~g}$ of silica gel with ethyl acetate/PE $(60 / 70)(1: 10)$ as eluent $\left(R_{f}\right.$ $=0.85$; ethyl acetate/dichloromethane $2: 8$ ) yielded $360 \mathrm{mg}(44 \%)$ of dimethyl [2.2]paracyclophan-1-ene-(E)-1,2-diacrylate (11e), $\mathrm{mp} 166^{\circ} \mathrm{C}$. IR $(\mathrm{KBr}): \nu 1710(\mathrm{C}=\mathrm{O}) \mathrm{cm}^{-1}$. ${ }^{1} \mathrm{H}$ NMR $\left(270 \mathrm{MHz}, \mathrm{CDCl}_{3}\right): \delta 3.08$ (s, $4 \mathrm{H}, \mathrm{H}-9,10), 3.80$ (s, $\left.6 \mathrm{H}, \mathrm{CO}_{2} \mathrm{CH}_{3}\right), 6.20$ (d, $\left.{ }^{3} J=15.6 \mathrm{~Hz}, \mathrm{H}-2^{\prime}, 2^{\prime \prime}\right)$, 6.47 (AB system, $\delta_{\mathrm{A}}=6.55, \delta_{\mathrm{B}}=6.40,{ }^{3} J_{\mathrm{AB}}=7.5 \mathrm{~Hz}, 8 \mathrm{H}, \mathrm{H}$-arene of paracyclophane), $8.33\left(\mathrm{~d},{ }^{3} \mathrm{~J}=15.6 \mathrm{~Hz}, \mathrm{H}-1^{\prime}, 1^{\prime \prime}\right),{ }^{13} \mathrm{C}$ NMR $(100.6$ $\left.\mathrm{MHz}, \mathrm{CDCl}_{3}\right): \delta 34.70(-, \mathrm{C}-9,10), 51.77\left(+, \mathrm{CO}_{2} \mathrm{CH}_{3}\right), 125.46(+$, C-2 $\left.2^{\prime}, 2^{\prime \prime}\right), 131.94(+, \mathrm{C}$-arene of paracyclophane $), 132.77(+, \mathrm{C}$-arene of paracyclophane), $137.23\left(\mathrm{C}_{\text {quat }}\right), 138.38\left(+, \mathrm{C}-1^{\prime}, 1^{\prime \prime}\right), 139.70\left(\mathrm{C}_{\text {quat }}\right)$, $148.00\left(C_{\text {quat }}\right), 167.24\left(\mathrm{C}_{\text {quat }}, \mathrm{C}=0\right)$. MS $(70 \mathrm{eV}) \mathrm{m} / \mathrm{z}(\%): 290(100$, $\mathrm{M}^{+}$).

A solution of $747 \mathrm{mg}(2.0 \mathrm{mmol})$ of $11 \mathrm{e}$ in $40 \mathrm{~mL}$ of $x y l e n e$ was heated under reflux for $1 \mathrm{~h} ; 500 \mathrm{mg}(2.2 \mathrm{mmol})$ of DDQ was added, and the mixture was refluxed for $5 \mathrm{~h}$. Chromatography on $50 \mathrm{~g}$ of silica gel with ethyl acetate/PE $(60 / 70) 1: 9\left(R_{f}=0.06\right)$ and ethyl acetate/dichloromethane 1:10 $\left(R_{f}=0.53\right)$ as eluents and recrystallization from heptane yielded $336 \mathrm{mg}(45 \%)$ of $12 \mathrm{e}, \mathrm{mp} 208{ }^{\circ} \mathrm{C}$. IR $(\mathrm{KBr}): \nu 1720(\mathrm{C}=\mathrm{O})$ $\mathrm{cm}^{-1},{ }^{1} \mathrm{H}$ NMR $\left(270 \mathrm{MHz} \mathrm{CDCl}_{3}\right): \delta 3.13(\mathrm{~s}, 4 \mathrm{H}, \mathrm{H}-9,10), 3.98(\mathrm{~s}$, $6 \mathrm{H}, \mathrm{CO}_{2} \mathrm{CH}_{3}$ ), 6.55 (AB system, $\delta_{\mathrm{A}}=6.59, \delta_{\mathrm{B}}=6.51,{ }^{3} \mathrm{~J}=7.2 \mathrm{~Hz}, 8$ $\mathrm{H}, \mathrm{H}$-arene of paracyclophane), $7.94\left(\mathrm{~s}, 2 \mathrm{H}, \mathrm{H}\right.$-arene), ${ }^{13} \mathrm{C}$ NMR (100 $\left.\mathrm{MHz}, \mathrm{CDCl}_{3}\right): \delta 34.60(-, \mathrm{C}-9,10), 52.75\left(+, \mathrm{CO}_{2} \mathrm{CH}_{3}\right), 126.23(+$, C-3', $\left.6^{\prime}\right), 130.55\left(C_{\text {quat }}\right), 132.07(+), 132.46(+), 138.24\left(C_{\text {quat }}\right), 139.97$ $\left(\mathrm{C}_{\text {quat }}\right), 148.82\left(\mathrm{C}_{\text {quat }}\right), 167.99\left(\mathrm{C}_{\text {quat }}, \mathrm{C}=\mathrm{O}\right) . \mathrm{MS}(70 \mathrm{eV}) \mathrm{m} / \mathrm{z}(\%): 372$ $\left(100, \mathrm{M}^{+}\right)$. Anal. Caled for $\mathrm{C}_{24} \mathrm{H}_{20} \mathrm{O}_{4}: \mathrm{C}, 77.48 ; \mathrm{H}, 5.38$. Found: $\mathrm{C}$, $77.41 ; \mathrm{H}, 5.43$.

4',5'-Diphenyl-1,2-benzo[2.2]paracyclophan-1-ene (12f). 5(1.00 g, 2.75 $\mathrm{mmol})$ and $2.5 \mathrm{~mL}(22 \mathrm{mmol})$ of styrene were reacted as described in GP 1 for 3 days at $100^{\circ} \mathrm{C}$. The crude product was chromatographed on $50 \mathrm{~g}$ of silica gel (dichloromethane/PE $\left.(60 / 70) 1: 1, R_{f}=0.7\right)$, yielding $654 \mathrm{mg}(58 \%)$ of 1,2-distyryl[2.2] paracyclophan-1-ene (11f), mp 260 ${ }^{\circ} \mathrm{C}$. 'H NMR $\left(270 \mathrm{MHz}, \mathrm{CDCl}_{3}\right): \delta 3.15(\mathrm{~s}, 4 \mathrm{H}, \mathrm{H}-9,10), 6.65(\mathrm{AB}$ system, $\delta_{\mathrm{A}}=6.60, \delta_{\mathrm{B}}=6.70,{ }^{3} J_{\mathrm{AB}}=8 \mathrm{~Hz}, 8 \mathrm{H}, \mathrm{H}$-arene of paracyclophane), $6.88\left(\mathrm{~d},{ }^{3} J=15.6 \mathrm{~Hz}, 2 \mathrm{H}\right), 7.32(\mathrm{~m}, 10 \mathrm{H}, \mathrm{H}$-phenyl), $7.90\left(\mathrm{~d},{ }^{3} \mathrm{~J}=15.6 \mathrm{~Hz}, 2 \mathrm{H}\right)$. Anal. Calcd for $\mathrm{C}_{32} \mathrm{H}_{26}: \mathrm{C}, 93.66 ; \mathrm{H}, 6.34$. Found: $\mathrm{C}, 93.85 ; \mathrm{H}, 6.36$

$11 \mathrm{f}(650 \mathrm{mg}, 1.58 \mathrm{mmol}$ ) was heated in $50 \mathrm{~mL}$ of xylene for $1 \mathrm{~h}$ at $140^{\circ} \mathrm{C}$. DDQ (430 mg, $1.9 \mathrm{mmol}$ ) was added, and the mixture was refluxed for $5 \mathrm{~h}$. Chromatography on $50 \mathrm{~g}$ of silica gel (dichloromethane/ hexane $1: 4, R_{f}=0.42$ ) and recrystallization from heptane yielded 341 $\mathrm{mg}(53 \%)$ of $12 \mathrm{f}, \mathrm{mp}>280^{\circ} \mathrm{C}$. ${ }^{1} \mathrm{H}$ NMR $\left(250 \mathrm{MHz}, \mathrm{CDCl}_{3}\right): \delta 3.15$ $(\mathrm{s}, 4 \mathrm{H}, \mathrm{H}-9,10), 6.65\left(\mathrm{AB}\right.$ system, $\delta_{\mathrm{A}}=6.60, \delta_{\mathrm{B}}=6.70,{ }^{3} J_{\mathrm{AB}}=8 \mathrm{~Hz}$, $8 \mathrm{H}, \mathrm{H}$-arene of paracyclophane), $7.30(\mathrm{~m}, 10 \mathrm{H}, \mathrm{H}$-phenyl), $7.70(\mathrm{~s}, 2$ $\mathrm{H}, \mathrm{H}$-arene). ${ }^{13} \mathrm{CNMR}\left(100 \mathrm{MHz}, \mathrm{CDCl}_{3}\right): \delta 34.85(-), 126.53,127.95$, $130.04,132.30$ and $132.43(+), 138.89,139.37,139.87,141.33$ and 144.94 $\left(\mathrm{C}_{\text {quat }}\right)$. MS $(70 \mathrm{eV}) \mathrm{m} / z(\%): 408\left(100, \mathrm{M}^{+}\right)$.

$4^{\prime}, 5^{\prime}$-Bis (p-carbomethoxyphenyl)-1,2-benzo[ 2.2]paracyclophan-1-ene (12i). $5(2.0 \mathrm{~g}, 5.5 \mathrm{mmol})$ and $3.6 \mathrm{~g}(22 \mathrm{mmol})$ of methyl p-vinylbenzoate were reacted following GP 1 under sonification for 1 day at $70^{\circ} \mathrm{C}$ Chromatography on $50 \mathrm{~g}$ of silica gel (dichloromethane/PE (60/70) $2: 1$, $R_{f}=0.44$ ) yielded $1.66 \mathrm{~g}(57 \%)$ of 1,2 -bis ( $p$-carbomethoxystyryl) [2.2]paracyclophan-1-ene (11i). ${ }^{1} \mathrm{H}$ NMR $\left(270 \mathrm{MHz}, \mathrm{CDCl}_{3}\right): \delta 3.07(\mathrm{~s}, 4$ $\mathrm{H}), 3.91\left(\mathrm{~s}, 6 \mathrm{H}, \mathrm{CO}_{2} \mathrm{CH}_{3}\right), 6.51\left(\mathrm{AB}\right.$ system, $\delta_{\mathrm{A}}=6.55, \delta_{\mathrm{B}}=6.46,{ }^{3} J_{\mathrm{AB}}$ $=8.8 \mathrm{~Hz}, 8 \mathrm{H}, \mathrm{H}$-arene of paracyclophane $), 6.85\left(\mathrm{~d},{ }^{3} J=15.4 \mathrm{~Hz}, 2 \mathrm{H}\right)$, $7.78\left(\mathrm{AB}\right.$ system, $\delta_{\mathrm{A}}=8.01, \delta_{\mathrm{B}}=7.55,{ }^{3} J_{\mathrm{AB}}=8.4 \mathrm{~Hz}, 8 \mathrm{H}, \mathrm{H}$-arene), $7.93\left(\mathrm{~d},{ }^{3} \mathrm{~J}=15.4 \mathrm{~Hz}, 2 \mathrm{H}\right) .{ }^{13} \mathrm{C} \mathrm{NMR}\left(68 \mathrm{MHz}, \mathrm{CDCl}_{3}\right): \delta 34.90(-)$, $51.89\left(+, \mathrm{CO}_{2} \mathrm{CH}_{3}\right), 126.67(+), 127.06(+), 129.66\left(\mathrm{C}_{\text {quat }}\right), 130.09(+)$, $132.57(+), 132.69(+), 134.96(+), 139.25\left(C_{\text {quat }}\right.$, relative intensity 2$)$, $142.05\left(C_{\text {quat }}\right), 145.42\left(C_{\text {quat }}\right), 166.73\left(C_{\text {quat }}\right)$. MS $(70 \mathrm{eV}) \mathrm{m} / \mathrm{z}(\%)$ : $526\left(100, \mathrm{M}^{+}\right)$

$11 \mathrm{i}(1.61 \mathrm{~g}, 3.0 \mathrm{mmol})$ and $120 \mathrm{mg}(3.7 \mathrm{mmol})$ of sulfur were refluxed in $50 \mathrm{~mL}$ of xylene for $12 \mathrm{~h}$. The solvent was removed in vacuo, the solid residue was chromatographed on $50 \mathrm{~g}$ of silica gel (dichloromethane, $R$ $=0.6)$, and the product was recrystallized from toluene/PE (60/70) $1: 1$, yielding $1.05 \mathrm{~g}(65 \%)$ of $12 \mathrm{i}, \mathrm{mp} 242^{\circ} \mathrm{C}$. IR (KBr): $\nu 1725 \mathrm{~cm}^{-1}(\mathrm{C}=\mathrm{O})$. ${ }^{1} \mathrm{H} \mathrm{NMR}\left(270 \mathrm{MHz}, \mathrm{CDCl}_{3}\right): \delta 3.11(\mathrm{~s}, 4 \mathrm{H}, \mathrm{H}-9(10)), 3.89(\mathrm{~s}, 6 \mathrm{H}$, $\left.\mathrm{CO}_{2} \mathrm{CH}_{3}\right), 6.59(\mathrm{~s}, 8 \mathrm{H}, \mathrm{H}$-arene of paracyclophane), 7.66 (AB system, $\left.\delta_{\mathrm{A}}=7.94, \delta_{\mathrm{B}}=7.39,{ }^{3} J_{\mathrm{AB}}=8.4 \mathrm{~Hz}, 8 \mathrm{H}\right), 7.68(\mathrm{~s}, 2 \mathrm{H}, \mathrm{H}$-arene $) . \mathrm{MS}$ $(70 \mathrm{eV}) \mathrm{m} / \mathrm{z}(\%): 524\left(52, \mathrm{M}^{+}\right)$.
General Procedure for the Coupling of 6 with Alkenes (GP 2). 6 (1.0 $\mathrm{mmol}), 10.0 \mathrm{mmol}$ of $\mathrm{K}_{2} \mathrm{CO}_{3}, 4.0 \mathrm{mmol}$ of $\mathrm{Bu}_{4} \mathrm{NBr}$, the specified amount of the alkene, and $25 \mathrm{mg}(0.11 \mathrm{mmol})$ of $\mathrm{Pd}(\mathrm{OAc})_{2}$ in $20 \mathrm{~mL}$ of anhydrous DMF under nitrogen were heated in a capped Pyrex bottle. At the end of the reaction the mixture was filtered, diluted with $100 \mathrm{~mL}$ of dichloromethane, and washed with five $50-\mathrm{mL}$ portions of water. The aqueous phases were extracted with $50 \mathrm{~mL}$ of dichloromethane. The filtration residue was extracted with $200 \mathrm{~mL}$ of hot chloroform. All organic phases were combined, dried over $\mathrm{MgSO}_{4}$, and evaporated to dryness in vacuo, and the crude products were chromatographed on silica gel. The obtained trienes were dissolved in $50 \mathrm{~mL}$ of xylene and refluxed for $1 \mathrm{~h}$. After addition of equimolar amounts of DDQ or sulfur, the mixture was refluxed for $3 \mathrm{~h}$, the solvent was removed in vacuo, and the crude products were purified by chromatography on silica gel.

1,2:9,10-Dibenzo[2.2]paracyclophane-1,9-diene (1a). (A) Following GP $2,500 \mathrm{mg}(0.96 \mathrm{mmol})$ of 6 was reacted under a pressure of $3 \times 10^{5}$ $\mathrm{Pa}$ of ethylene for 2 days at $100^{\circ} \mathrm{C}$. The crude product was chromatographed on silica gel (dichloromethane/hexane $1: 1, R_{f}=0.9$ ), yielding $70 \mathrm{mg}$ (24\%) of 1,2,9,10-tetravinyl [2.2] paracyclophane-1,9-diene (9a). ${ }^{1} \mathrm{H}$ NMR $\left(270 \mathrm{MHz}, \mathrm{CDCl}_{3}\right): \delta 5.45\left(\mathrm{~m},{ }^{3} J_{\mathrm{cis}}=10 \mathrm{~Hz},{ }^{3} J_{\text {trans }}=\right.$ $17 \mathrm{~Hz}, 8 \mathrm{H}, \mathrm{H}$-olefin), 6.53 (s, $8 \mathrm{H}, \mathrm{H}$-arene of paracyclophane), 7.30 (dd, ${ }^{3} J_{\text {cis }}=10 \mathrm{~Hz},{ }^{3} J_{\text {trans }}=17 \mathrm{~Hz}, 4 \mathrm{H}, \mathrm{H}$-olefin).

According to GP $2,9 \mathrm{a}$ was cyclized and dehydrogenated with $15 \mathrm{mg}$ $(0.5 \mathrm{mmol})$ of sulfur, yielding after chromatography on $10 \mathrm{~g}$ of silica gel (hexane, $R_{f}=0.15$ ) $54 \mathrm{mg}$ of 1a. Recrystallization from hexane afforded $40 \mathrm{mg}(58 \%)$ of pure 1a. All spectroscopic data are identical with those previously reported. 8,9

(B) $6(1.00 \mathrm{~g}, 1.92 \mathrm{mmol})$ and $2.35 \mathrm{~mL}(14.7 \mathrm{mmol})$ of trimethylvinylsilane were reacted as described in GP 2 for 5 days at $40^{\circ} \mathrm{C}$. The crude product was chromatographed on $50 \mathrm{~g}$ of silica gel (dichloromethane/hexane, $R_{f}=0.9$ ), and the so obtained material was oxidized with $55 \mathrm{mg}(1.7 \mathrm{mmol})$ of sulfur following GP 2 . Chromatography on $50 \mathrm{~g}$ of silica gel (hexane, $R_{f}=0.15$ ) and recrystallization from hexane yielded $122 \mathrm{mg}$ (21\%) of 1a. According to the ${ }^{1} \mathrm{H}$ NMR spectra of $1 \mathrm{a}$, more than $95 \%$ of the trimethylsilyl groups were cleaved. All other signals are identical with the reported ones. 8,9

[2.2]Paracyclophane-1,9-diene-1,2,9,10-tetraacrylaldehyde (9d). 6 $(500 \mathrm{mg}, 0.96 \mathrm{mmol})$ and $1.0 \mathrm{~mL}(15 \mathrm{mmol})$ of acrolein were reacted following GP 2 for $12 \mathrm{~h}$ under sonification at room temperature. Instead of $\mathrm{K}_{2} \mathrm{CO}_{3}, 800 \mathrm{mg}$ ( $9.6 \mathrm{mmol}$ ) of $\mathrm{NaHCO}_{3}$ was used as base. The crude product was chromatographed on $50 \mathrm{~g}$ of silica gel (dichloromethane/ ethyl acetate $3: 1, R_{f}=0.5$ ), yielding $156 \mathrm{mg}(38 \%)$ of $9 \mathrm{~d}$ as a yellow solid. IR (KBr): $\nu 1660(\mathrm{C}=0) \mathrm{cm}^{-1}$. ${ }^{1} \mathrm{H}$ NMR $\left(270 \mathrm{MHz}, \mathrm{CDCl}_{3}\right): \delta 6.45$ (dd, $\left.{ }^{3} J=15.2 \mathrm{~Hz},{ }^{3} J=7.8 \mathrm{~Hz}, 4 \mathrm{H}, 2^{\prime}-\mathrm{H}\right), 6.62(\mathrm{~s}, 8 \mathrm{H}, \mathrm{H}$-arene of paracyclophane), $8.15\left(\mathrm{~d},{ }^{3} J=15.2 \mathrm{~Hz}, 4 \mathrm{H}, 3^{\prime}-\mathrm{H}\right), 9.90\left(\mathrm{~d},{ }^{3} J=7.8\right.$ $\mathrm{Hz}, 4 \mathrm{H}, \mathrm{CHO}$ ).

No products could be isolated after the dehydrogenation of $9 \mathrm{~d}$ with sulfur in xylene.

$4^{\prime}, 4^{\prime \prime}, 5^{\prime}, 5^{\prime \prime}$-Tetracarbomethoxy-1,2:9,10-dibenzo[ 2.2]paracyclophane1,9-diene (1e). $6(1.00 \mathrm{~g}, 1.92 \mathrm{mmol})$ and $1.75 \mathrm{~g}(1.7 \mathrm{~mL}, 19.2 \mathrm{mmol})$ of methyl acrylate were reacted as described in GP 2 for $12 \mathrm{~h}$ at $60^{\circ} \mathrm{C}$ under sonification. Chromatography on $50 \mathrm{~g}$ of silica gel (dichloromethane, $R_{f}=0.3$ ) and recrystallization from dichloromethane/hexane (1:1) afforded $502 \mathrm{mg}$ (48\%) of tetramethyl [2.2]paracyclophane-1,9diene-1,2,9,10-tetraacrylate (9e) as yellow crystals. IR (KBr): $\nu 1730$ $(\mathrm{C}=\mathrm{O}) \mathrm{cm}^{-1}$. ${ }^{1} \mathrm{H} \mathrm{NMR}\left(270 \mathrm{MHz}, \mathrm{CDCl}_{3}\right): \delta 3.79\left(\mathrm{~s}, 12 \mathrm{H}, \mathrm{CO}_{2} \mathrm{CH}_{3}\right)$, $6.16\left(\mathrm{~d},{ }^{3} \mathrm{~J}=15.2 \mathrm{~Hz}, 4 \mathrm{H}, \mathrm{H}\right.$-olefin $), 6.54(\mathrm{~s}, 8 \mathrm{H}, \mathrm{H}$-arene of paracyclophane), 8.29 (d, ${ }^{3} \mathrm{~J}=15.2 \mathrm{~Hz}, 4 \mathrm{H}, \mathrm{H}$-olefin). ${ }^{13} \mathrm{C}$ NMR (68 $\left.\mathrm{MHz}, \mathrm{CDCl}_{3}\right): \delta 51.60\left(+, \mathrm{CO}_{2} \mathrm{CH}_{3}\right), 126.32(+, \mathrm{C}$-olefin $), 131.58(+$, $\mathrm{C}$-arene of paracyclophane), $137.62(+, \mathrm{C}$-olefin $), 138.58\left(\mathrm{C}_{\text {quat }}\right), 147.02$ $\left(C_{\text {quat }}, \mathrm{C}-\mathrm{l}(2)\right), 166.92\left(\mathrm{C}_{\text {quat }}, \mathrm{C}=\mathrm{O}\right) . \mathrm{MS}(70 \mathrm{eV}) \mathrm{m} / \mathrm{z}(\%): 540(66$, $\left.\mathrm{M}^{+}\right), 481\left(100, \mathrm{M}^{+}-\mathrm{CO}_{2} \mathrm{CH}_{3}\right), 422\left(16, \mathrm{M}^{+}-2 \mathrm{CO}_{2} \mathrm{CH}_{3}\right), 363(15$, $\left.\mathrm{M}^{+}-3 \mathrm{CO}_{2} \mathrm{CH}_{3}\right), 304\left(27, \mathrm{M}^{+}-4 \mathrm{CO}_{2} \mathrm{CH}_{3}\right)$. Anal. Calcd for $\mathrm{C}_{32} \mathrm{H}_{28} \mathrm{O}_{8}: 540.1784$. Found 540.1807 (MS).

9 e $(500 \mathrm{mg}, 0.92 \mathrm{mmol})$ and $80 \mathrm{mg}(2.5 \mathrm{mmol})$ of sulfur were reacted following GP 2. The crude product was chromatographed on $50 \mathrm{~g}$ of silica gel (dichloromethane, $R_{f}=0.3$ ); recrystallization from toluene/ heptane (1:1) afforded $212 \mathrm{mg}(43 \%)$ of 1e. IR $(\mathrm{KBr}): \nu 1720(\mathrm{C}=\mathrm{O})$ $\mathrm{cm}^{-1}$. ${ }^{1} \mathrm{H}$ NMR $\left(270 \mathrm{MHz}, \mathrm{CDCl}_{3}\right): \delta 3.97\left(\mathrm{~s}, 12 \mathrm{H}, \mathrm{CO}_{2} \mathrm{CH}_{3}\right), 6.67$ (s, $8 \mathrm{H}, \mathrm{H}$-arene of paracyclophane), $8.00(\mathrm{~s}, 4 \mathrm{H}) .{ }^{13} \mathrm{C} \mathrm{NMR}(68 \mathrm{MHz}$, $\left.\mathrm{CDCl}_{3}\right): \delta 52.73\left(+, \mathrm{CO}_{2} \mathrm{CH}_{3}\right), 126.22(+), 131.13\left(\mathrm{C}_{\text {quat }}\right), 131.55(+)$, $139.18\left(\mathrm{C}_{\text {quat }}\right), 147.59\left(\mathrm{C}_{\text {quat }}\right), 167.71\left(\mathrm{C}_{\text {quat }}, \mathrm{C}=\mathrm{O}\right)$. MS $(70 \mathrm{eV}) \mathrm{m} / \mathrm{z}$ (\%): $536\left(100, \mathrm{M}^{+}\right), 300\left(13, \mathrm{M}^{+}-4 \mathrm{CO}_{2} \mathrm{CH}_{3}\right)$. Anal. Calcd for $\mathrm{C}_{32} \mathrm{H}_{24} \mathrm{O}_{8}: \mathrm{C}, 71.60 ; \mathrm{H}, 4.50$. Found: $\mathrm{C}, 71.70 ; \mathrm{H}, 4.40$.

9,10-Dibromo-4',5'-dicarbomethoxy-1,2-benzo[2.2]paracyclophane-1,9diene (10e). $6(1.0 \mathrm{~g}, 1.92 \mathrm{mmol})$ and $1.75 \mathrm{~g}(1.7 \mathrm{~mL}, 19.2 \mathrm{mmol})$ of 
methyl acrylate were reacted according to GP 2 at $60^{\circ} \mathrm{C}$ under sonification for $2 \mathrm{~h}$. Chromatography of the crude product mixture on $50 \mathrm{~g}$ of silica gel (dichloromethane) yielded $80 \mathrm{mg}(8 \%)$ of $7 \mathrm{~d}$ (fraction $\mathrm{I}, R_{f}=0.7$ ). IR (KBr): $\nu 1720(\mathrm{C}=0) \mathrm{cm}^{-1}$. ${ }^{1} \mathrm{H}$ NMR $\left(270 \mathrm{MHz}, \mathrm{CDCl}_{3}\right): \delta 3.81$ (s, $\left.6 \mathrm{H}, \mathrm{CO}_{2} \mathrm{CH}_{3}\right), 6.13\left(\mathrm{~d},{ }^{3} \mathrm{~J}=15.4 \mathrm{~Hz}, 2 \mathrm{H}, \mathrm{H}\right.$-olefin), $6.69(\mathrm{AB}$ system, $\delta_{\mathrm{A}}=6.78, \delta_{\mathrm{B}}=6.59,{ }^{3} \mathrm{~J}=8.4 \mathrm{~Hz}, 8 \mathrm{H}, \mathrm{H}$-arene of paracyclophane), $8.30\left(\mathrm{~d},{ }^{3} J=15.4 \mathrm{~Hz}, 2 \mathrm{H}\right.$, H-olefin). ${ }^{13} \mathrm{C} \mathrm{NMR}\left(68 \mathrm{MHz}, \mathrm{CDCl}_{3}\right)$ : $\delta 51.81\left(+, \mathrm{CO}_{2} \mathrm{CH}_{3}\right), 123.82\left(\mathrm{C}_{\text {quat }}\right), 126.54(+), 131.05(+), 131.34$ $(+), 137.65(+), 139.55\left(\mathrm{C}_{\text {quat }}\right), 139.97\left(\mathrm{C}_{\text {quat }}\right), 146.45\left(\mathrm{C}_{\text {quat }}\right), 166.78$ $\left(\mathrm{C}_{\text {quat }}, \mathrm{C}=\mathrm{O}\right)$. $\mathrm{MS}(70 \mathrm{eV}) \mathrm{m} / \mathrm{z}(\%): 526 / 528 / 530\left(55 / 100 / 50, \mathrm{M}^{+}\right)$, $449 / 447\left(36 / 38, \mathrm{M}^{+}-\mathrm{Br}\right), 368\left(13, \mathrm{M}^{+}-2 \mathrm{Br}\right)$. II $\left(R_{f}=0.3\right): 413$ mg $(40 \%)$ of $9 e$.

$4^{\prime}, 4^{\prime \prime}, 5^{\prime}, 5^{\prime \prime}$-Tetraphenyl-1,2:9,10-dibenzo[2.2]paracyclophane-1,9-diene (1f). $6(1.50 \mathrm{~g}, 2.9 \mathrm{mmol})$ was reacted with $5.0 \mathrm{~mL}(43.6 \mathrm{mmol})$ of styrene for 3 days at $100^{\circ} \mathrm{C}$ following GP 2 . The crude product was chromatographed on $50 \mathrm{~g}$ of silica gel (dichloromethane/hexane 1:1, $R_{f}$ $=0.76$ ), yielding $971 \mathrm{mg}(55 \%)$ of $1,2,9,10$-tetrastyryl [2.2]paracyclophane1,9-diene (9f) as a yellow solid. ' $\mathrm{H}$ NMR $\left(270 \mathrm{MHz}, \mathrm{CDCl}_{3}\right): \delta 6.68$ (s, $8 \mathrm{H}, \mathrm{H}$-arene of paracyclophane), $6.87\left(\mathrm{~d},{ }^{3} \mathrm{~J}=15.6 \mathrm{~Hz}, 4 \mathrm{H}\right), 7.31$ $7.58\left(\mathrm{~m}, 20 \mathrm{H}, \mathrm{H}\right.$-phenyl), $7.91\left(\mathrm{~d},{ }^{3} \mathrm{~J}=15.6 \mathrm{~Hz}, 4 \mathrm{H}\right) . \quad \mathrm{MS}(70 \mathrm{eV})$ $m / z(\%): 612\left(100, \mathrm{M}^{+}\right)$.

9f was dehydrogenated with $105 \mathrm{mg}(3.3 \mathrm{mmol})$ of sulfur, as described in GP 2. Chromatography on $50 \mathrm{~g}$ of silica gel (dichloromethane/hexane $1: 4)$ and recrystallization from toluene/hexane (2:1) afforded $482 \mathrm{mg}$ (28\%) of 1f, $\mathrm{mp}>280^{\circ} \mathrm{C}$. ${ }^{1} \mathrm{H}$ NMR $\left(270 \mathrm{MHz}, \mathrm{CDCl}_{3}\right): \delta 6.79(\mathrm{~s}, 8$ $\mathrm{H}, \mathrm{H}$-arene of paracyclophane), 7.24-7.28 (m, $20 \mathrm{H}, \mathrm{H}$-phenyl), 7.74 (s, $4 \mathrm{H}) .{ }^{13} \mathrm{C}$ NMR $\left(68 \mathrm{MHz}, \mathrm{CDCl}_{3}\right): \delta 122.66,127.91,128.00,130.12$ and $131.76(+), 139.42,140.29,141.51$ and $144.22\left(\mathrm{C}_{\text {quat }}\right)$. MS $(70 \mathrm{eV})$ $m / z(\%): 608\left(100, \mathrm{M}^{+}\right)$. Anal. Calcd for $\mathrm{C}_{48} \mathrm{H}_{32}: 608.2504$. Found: 608.2504 (MS).

9,10-Dibromo-4',5'-diphenyl-1,2-benzo [2.2]paracyclophane-1,9-diene (10f). $6(1.0 \mathrm{~g}, 1.9 \mathrm{mmol})$ and $3.5 \mathrm{~mL}(30.5 \mathrm{mmol})$ of styrene were reacted according to GP 2 at $60^{\circ} \mathrm{C}$ for 1 day. The crude product was chromatographed on $50 \mathrm{~g}$ of silica gel (dichloromethane/hexane $1: 1, R_{f}$ $=0.76$ ), yielding $610 \mathrm{mg}$ of $7 \mathrm{e}$. Dehydrogenation with $65 \mathrm{mg}(2.0 \mathrm{mmol})$ of sulfur, chromatography on $25 \mathrm{~g}$ of silica gel (dichloromethane/hexane $1: 4, R_{f}=0.37$ ), and recrystallization from toluene/hexane (2:1) afforded $392 \mathrm{mg}(36 \%)$ of 9,10 -dibromo-4 $4^{\prime}, 5^{\prime}$-diphenyl-1,2-benzo[2.2]paracyclophane-1,9-diene. ${ }^{1} \mathrm{H}$ NMR $\left(270 \mathrm{MHz}, \mathrm{CDCl}_{3}\right): \delta 6.76(\mathrm{~b} \mathrm{~s}$, $8 \mathrm{H}, \mathrm{H}$-arene of paracyclophane), $7.26(\mathrm{~b} \mathrm{~s}, 10 \mathrm{H}, \mathrm{H}$-phenyl), 7.70 (s, $2 \mathrm{H}) .{ }^{13} \mathrm{CNMR}\left(68 \mathrm{MHz}, \mathrm{CDCl}_{3}\right): \delta 124.05\left(\mathrm{C}_{\text {quat }}\right), 126.81(+), 127.69$ $(+), 128.05(+), 130.04(+), 132.06(+), 139.36\left(C_{\text {quat }}\right), 139.79\left(\mathrm{C}_{\text {quat }}\right)$ $141.22\left(\mathrm{C}_{\text {quat }}\right), 141.66\left(\mathrm{C}_{\text {quat }}\right), 142.83\left(\mathrm{C}_{\text {quat }}\right) . \quad \mathrm{MS}(70 \mathrm{eV}) \mathrm{m} / \mathrm{z}(\%)$ : $562 / 564 / 566\left(51 / 100 / 53, \mathrm{M}^{+}\right)$. Anal. Calcd for $\mathrm{C}_{32} \mathrm{H}_{20} \mathrm{Br}_{2}: \mathrm{C}, 68.11$; $\mathrm{H}, 3.57 ; \mathrm{Br}, 28.32$. Found: $\mathrm{C}, 68.14 ; \mathrm{H}, 3.60 ; \mathrm{Br}, 28.29$.

$4^{\prime}, 4^{\prime \prime}, 5^{\prime}, 5^{\prime \prime}$-Tetrakis(p-fluorophenyl)-1,2:9,10-dibenzo[2.2]paracyclophane1,9-diene (1g). $6(300 \mathrm{mg}, 0.58 \mathrm{mmol})$ and $550 \mathrm{mg}(4.5 \mathrm{mmol})$ of $p$-fluorostyrene were reacted for $12 \mathrm{~h}$ at $100^{\circ} \mathrm{C}$ according to GP 2 . Chromatography on $50 \mathrm{~g}$ of silica gel (dichloromethane/hexane 1:2, $R_{f}$ $=0.4)$ yielded $176 \mathrm{mg}(45 \%)$ of $9 \mathrm{~g}$. Without further purification $9 \mathrm{~g}$ was dehydrogenated with $80 \mathrm{mg}(2.5 \mathrm{mmol})$ of sulfur following GP 2 . The crude product was chromatographed on $50 \mathrm{~g}$ of silica gel (dichloromethane/hexane $1: 2, R_{f}=0.4$ ), yielding $80 \mathrm{mg}(20 \%)$ of $1 \mathrm{~g}, \mathrm{mp}>290$ ${ }^{\circ} \mathrm{C}$. IR (KBr): $\nu 2950,1600,1500,820 \mathrm{~cm}^{-1}$. ${ }^{1} \mathrm{H}$ NMR $(270 \mathrm{MHz}$, $\left.\mathrm{CDCl}_{3}\right): \delta 6.77$ (b s, $8 \mathrm{H}, \mathrm{H}$-arene of paracyclophane), $6.97(\mathrm{~m}, 16 \mathrm{H}$, $\mathrm{H}$-phenyl), 7.72 (b s, $4 \mathrm{H}, \mathrm{H}$-arene). MS (70 eV) $\mathrm{m} / z$ (\%): 680 (100, $\mathrm{M}^{+}$). Anal. Calcd for $\mathrm{C}_{48} \mathrm{H}_{28} \mathrm{~F}_{4}: 680.2127$. Found 680.2097 (MS).

$4^{\prime}, 4^{\prime \prime}, 5^{\prime}, 5^{\prime \prime}$-Tetrakis ( $p$-tert-butylphenyl)-1,2:9,10-dibenzo[2.2]paracyclophane-1,9-diene (1h). $6(1.00 \mathrm{~g}, 1.92 \mathrm{mmol})$ and $2.4 \mathrm{~g}(2.7 \mathrm{~mL}$, $15 \mathrm{mmol}$ ) of $p$-tert-butylstyrene were reacted at $100^{\circ} \mathrm{C}$ for $20 \mathrm{~h}$ according to GP 2. Chromatography on $50 \mathrm{~g}$ of silica gel (dichloromethane/hexane $\left.1: 4, R_{f}=0.29\right)$ yielded $880 \mathrm{mg}(55 \%)$ of $1,2,9,10$-tetrakis $(E)$-p-tertbutylstyryl) [2.2] paracyclophane-1,9-diene ( $9 \mathrm{~h})$ as a yellow solid. IR $(\mathrm{KBr}): \nu 3030,2960,2900,1450 \mathrm{~cm}^{-1}$. ${ }^{1} \mathrm{H}$ NMR $\left(270 \mathrm{MHz}, \mathrm{CDCl}_{3}\right)$ : $\delta 1.33\left[\mathrm{~s}, 36 \mathrm{H}, \mathrm{C}\left(\mathrm{CH}_{3}\right)_{3}\right], 6.66(\mathrm{~s}, 8 \mathrm{H}, \mathrm{H}$-arene of paracyclophane $), 6.84$ (d, ${ }^{3} J=15.6 \mathrm{~Hz}, 4 \mathrm{H}, \mathrm{H}$-olefin), 7.41 (AB system, $\delta_{\mathrm{A}}=7.46, \delta_{\mathrm{B}}=7.35$, ${ }^{3} J=8.4 \mathrm{~Hz}, 16 \mathrm{H}, \mathrm{H}$-phenyl), $7.87\left(\mathrm{~d},{ }^{3} J=15.6 \mathrm{~Hz}, 4 \mathrm{H}, \mathrm{H}\right.$-olefin).

$9 \mathrm{~h}(870 \mathrm{mg}, 1.04 \mathrm{mmol})$ was dehydrogenated with $80 \mathrm{mg}(2.5 \mathrm{mmol})$ of sulfur according to GP 2. Chromatography of the crude product on $50 \mathrm{~g}$ of silica gel (dichloromethane/hexane $1: 4, R_{f}=0.32$ ) and recrystallization from toluene/ethanol (1:1) afforded $390 \mathrm{mg}(25 \%)$ of lh, $\mathrm{mp}>290^{\circ} \mathrm{C}$. IR $(\mathrm{KBr}): \nu 3050,2950,2900,1450,1110 \mathrm{~cm}^{-1},{ }^{1} \mathrm{H}$ NMR $\left(270 \mathrm{MHz}, \mathrm{CDCl}_{3}\right): \delta 1.30\left[\mathrm{~s}, 36 \mathrm{H}, \mathrm{C}\left(\mathrm{CH}_{3}\right)_{3}\right], 6.77(\mathrm{~s}, 8 \mathrm{H}$, $\mathrm{H}$-arene of paracyclophane), 7.24 (AB system, $\delta_{\mathrm{A}}=7.27, \delta_{\mathrm{B}}=7.21,3 \mathrm{~J}$ $=8.8 \mathrm{~Hz}, 16 \mathrm{H}, \mathrm{H}$-phenyl $), 7.72(\mathrm{~s}, 4 \mathrm{H}, \mathrm{H}$-arene $) .{ }^{13} \mathrm{C} \mathrm{NMR}(68 \mathrm{MHz}$, $\left.\mathrm{CDCl}_{3}\right): \delta 31.46\left(+, \mathrm{C}\left(\mathrm{CH}_{3}\right)_{3}\right), 34.54\left(\mathrm{C}_{\text {quat }}, \mathrm{C}\left(\mathrm{CH}_{3}\right)_{3}\right), 124.78(+)$,
$127.83(+), 129.76(+), 131.75(+), 138.61\left(\mathrm{C}_{\text {quat }}\right), 139.35\left(\mathrm{C}_{\text {quat }}\right), 140.42$ $\left(\mathrm{C}_{\text {quat }}\right), 143.94\left(\mathrm{C}_{\text {quat }}\right), 149.62\left(\mathrm{C}_{\text {quat }}\right) . \mathrm{MS}(70 \mathrm{eV}) \mathrm{m} / \mathrm{z}(\%): 832(100$, $\mathrm{M}^{+}$). Anal. Calcd for $\mathrm{C}_{64} \mathrm{H}_{64}: \mathrm{C}, 92.26 ; \mathrm{H}, 7.74$. Found: $\mathrm{C}, 92.12 ; \mathrm{H}$, 7.70 .

$4^{\prime}, 4^{\prime \prime}, 5^{\prime}, 5^{\prime \prime}$-Tetrakis ( $p$-carbomethoxyphenyl)-1,2:9,10-dibenzo[2.2]paracyclophane-1,9-diene (1i). A mixture of $1.50 \mathrm{~g}(2.88 \mathrm{mmol})$ of 6 , $3.73 \mathrm{~g}(23.0 \mathrm{mmol})$ of methyl $p$-vinylbenzoate, $3.80 \mathrm{~g}(11.7 \mathrm{mmol})$ of $\mathrm{Bu}_{4} \mathrm{NBr}, 4.10 \mathrm{~g}(29.6 \mathrm{mmol})$ of $\mathrm{K}_{2} \mathrm{CO}_{3}$, and $25 \mathrm{mg}$ (11.05 mmol) of $\mathrm{Pd}(\mathrm{OAc})_{2}$ in $40 \mathrm{~mL}$ of dry DMF under nitrogen was heated at $70^{\circ} \mathrm{C}$ for $36 \mathrm{~h}$ under sonification. $\mathrm{Pd}(\mathrm{OAc})_{2}(25 \mathrm{mg})$ was added to the reaction mixture every $12 \mathrm{~h}$. After the end of the reaction, the mixture was diluted with $500 \mathrm{~mL}$ of dichloromethane and washed with four portions of 150 $\mathrm{mL}$ of water. The organic phase was concentrated to a volume of $50 \mathrm{~mL}$, and $50 \mathrm{~mL}$ of PE $(60 / 70)$ was added. The yellow precipitate $(1.3 \mathrm{~g}$ of 9i) was removed by filtration, and the filtrate was evaporated to dryness. The residue was chromatographed on $50 \mathrm{~g}$ of silica gel (dichloromethane, $R_{f}=0.5$ ) to yield $210 \mathrm{mg}$ of $9 \mathrm{i}$. Total yield: $1.51 \mathrm{~g}(58 \%)$ of $9 \mathrm{i}$. IR $(\mathrm{KBr}): \nu 1720(\mathrm{C}=\mathrm{O}) \mathrm{cm}^{-1}$. ${ }^{1} \mathrm{H}$ NMR $\left(270 \mathrm{MHz}, \mathrm{CDCl}_{3}\right): \delta 3.92(\mathrm{~s}$, $\left.12 \mathrm{H}, \mathrm{CO}_{2} \mathrm{CH}_{3}\right), 6.69\left(\mathrm{~s}, 8 \mathrm{H}, \mathrm{H}\right.$-arene of paracyclophane), $6.91\left(\mathrm{~d},{ }^{3} \mathrm{~J}\right.$ $=15.7 \mathrm{~Hz}, 4 \mathrm{H}, \mathrm{H}$-olefin), $7.82\left(\mathrm{AB}\right.$ system, $\delta_{\mathrm{A}}=8.04, \delta_{\mathrm{B}}=7.59,{ }^{3} \mathrm{~J}$ $=8.4 \mathrm{~Hz}, 16 \mathrm{H}, \mathrm{H}$-arene), $8.00\left(\mathrm{~d},{ }^{3} \mathrm{~J}=15.7 \mathrm{~Hz}, 4 \mathrm{H}, \mathrm{H}\right.$-olefin $) .{ }^{13} \mathrm{C}$ NMR $\left(68 \mathrm{MHz}, \mathrm{CDCl}_{3}\right): \delta 51.95\left(+, \mathrm{CO}_{2} \mathrm{CH}_{3}\right), 126.74(+$, relative intensity $=2), 129.69\left(C_{\text {quat }}\right), 130.17(+), 132.01(+), 135.14(+), 140.09$ $\left(\mathrm{C}_{\text {quat }}\right), 141.92\left(\mathrm{C}_{\text {quat }}\right), 144.66\left(\mathrm{C}_{\text {quat }}\right), 166.72\left(\mathrm{C}_{\text {quat }}, \mathrm{C}=\mathrm{O}\right)$. Anal. Calcd for $\mathrm{C}_{56} \mathrm{H}_{44} \mathrm{O}_{8}$ : C, 79.60; $\mathrm{H}, 5.25$. Found: C, 79.80; H, 5.34.

A solution of $1.45 \mathrm{~g}(1.72 \mathrm{mmol})$ of $9 \mathrm{i}$ and $200 \mathrm{mg}(6.25 \mathrm{mmol})$ of sulfur in $150 \mathrm{~mL}$ of xylene was refluxed for $48 \mathrm{~h}$. After $12 \mathrm{~h}$ at $4{ }^{\circ} \mathrm{C}$ the white precipitate ( $743 \mathrm{mg}$ of $1 \mathrm{i})$ was removed by filtration, the filtrate was evaporated to dryness, and the residue was chromatographed on 50 $\mathrm{g}$ of silica gel with dichloromethane $\left(R_{f}=0.9\right)$ and dichloromethane/ ethyl acetate (4:1) as eluents. Recrystallization of the crude product from toluene yielded $420 \mathrm{mg}$ of $1 \mathrm{i}$. Total yield: $1.16 \mathrm{~g}(80 \%)$ of $1 \mathrm{i}, \mathrm{mp}$ $>290{ }^{\circ} \mathrm{C}$. IR $(\mathrm{KBr}): \nu 1720(\mathrm{C}=\mathrm{O}) \mathrm{cm}^{-1}$. ${ }^{1} \mathrm{H}$ NMR $(270 \mathrm{MHz}$, $\left.\mathrm{CDCl}_{3}\right): \delta 3.90\left(\mathrm{~s}, 12 \mathrm{H}, \mathrm{CO}_{2} \mathrm{CH}_{3}\right), 6.79(\mathrm{~s}, 8 \mathrm{H}, \mathrm{H}$-arene of paracyclophane), 7.67 (AB system, $\delta_{\mathrm{A}}=8.00, \delta_{\mathrm{B}}=7.34,{ }^{3} J=8.0 \mathrm{~Hz}$, $16 \mathrm{H}, \mathrm{H}$-arene), $7.76(\mathrm{~s}, 4 \mathrm{H}) .{ }^{13} \mathrm{C}$ NMR $\left(68 \mathrm{MHz}^{\mathrm{M}} \mathrm{CDCl}_{3}\right): \delta 51.94$ $\left(+, \mathrm{CO}_{2} \mathrm{CH}_{3}\right), 127.83(+), 129.02\left(\mathrm{C}_{\text {quat }}\right), 129.54(+), 130.05(+), 131.79$ $(+), 138.58\left(\mathrm{C}_{\text {quat }}\right), 139.96\left(\mathrm{C}_{\text {quat }}\right), 144.93\left(\mathrm{C}_{\text {quat }}\right), 145.68\left(\mathrm{C}_{\text {quat }}\right), 166.62$ $\left(\mathrm{C}_{\text {quat }}, \mathrm{C}=\mathrm{O}\right)$. MS $(70 \mathrm{eV}) \mathrm{m} / \mathrm{z}(\%): 840\left(32, \mathrm{M}^{+}\right), 91\left(100, \mathrm{C}_{7} \mathrm{H}_{7}{ }^{+}\right)$. Anal. Calcd for $\mathrm{C}_{56} \mathrm{H}_{40} \mathrm{O}_{8}: \mathrm{C}, 79.98 ; \mathrm{H}, 4.79$. Found: $\mathrm{C}, 80.05 ; \mathrm{H}$, 4.93 .

$4^{\prime}, 4^{\prime \prime}, 5^{\prime}, 5^{\prime \prime}$-Tetra(biphenylyl)-1,2:9,10-dibenzo[2.2]paracyclophane-1,9diene (1j). 6 (960 mg, $1.7 \mathrm{mmol}), 2.40 \mathrm{~g}$ (13.3 mmol) of 4-vinylbiphenyl, $2.36 \mathrm{~g}(17.1 \mathrm{mmol})$ of $\mathrm{K}_{2} \mathrm{CO}_{3}, 2.2 \mathrm{~g}(6.8 \mathrm{mmol})$ of $\mathrm{Bu}_{4} \mathrm{NBr}$, and $43 \mathrm{mg}$ $(0.19 \mathrm{mmol})$ of $\mathrm{Pd}(\mathrm{OAc})_{2}$ in $35 \mathrm{~mL}$ of anhydrous DMF was heated under nitrogen for 4 days at $100^{\circ} \mathrm{C}$. The reaction mixture was diluted with $200 \mathrm{~mL}$ of dichloromethane, filtered, washed with five portions of 100 $\mathrm{mL}$ of water, dried over $\mathrm{MgSO}_{4}$, and evaporated in vacuo. Chromatography on $80 \mathrm{~g}$ of silica gel (dichloromethane/PE $(60 / 70) 1: 1, R_{f}=$ 0.2 ) yielded $233 \mathrm{mg}$ (15\%) of 1,2,9,10-tetrakis (p-phenylstyryl) [2.2]paracyclophane-1,9-diene $(9 \mathrm{j})$ as a yellow solid. IR (KBr): $\nu 3026,1600$, $1486,761 \mathrm{~cm}^{-1}$. ${ }^{1} \mathrm{H}$ NMR $\left(250 \mathrm{MHz}, \mathrm{CDCl}_{3}\right): \delta 6.75(\mathrm{~s}, 8 \mathrm{H}, \mathrm{H}$-arene of paracyclophane), $6.95\left(\mathrm{~d},{ }^{3} \mathrm{~J}=15.4 \mathrm{~Hz}, 4 \mathrm{H}\right), 7.25-7.70(\mathrm{~m}, 36 \mathrm{H})$, $8.05\left(\mathrm{~d},{ }^{3} \mathrm{~J}=15.4 \mathrm{~Hz}, 4 \mathrm{H}\right)$.

$9 j$ ( $220 \mathrm{mg}, 0.24 \mathrm{mmol}$ ) in $100 \mathrm{~mL}$ of xylene was refluxed for a total of $7 \mathrm{~h}$; after $1 \mathrm{~h} 210 \mathrm{mg}(0.93 \mathrm{mmol})$ of DDQ was added. Chromatography on $80 \mathrm{~g}$ of silica gel (dichloromethane, $R_{f}=0.5$ ) yielded $68 \mathrm{mg}(31 \%)$ of $1 \mathrm{j}, \mathrm{mp}>280^{\circ} \mathrm{C}$. IR $(\mathrm{KBr}): v 3027,1486,765,697 \mathrm{~cm}^{-1}$. ${ }^{1} \mathrm{H}$ NMR $\left(250 \mathrm{MHz}, \mathrm{CDCl}_{3}\right): \delta 6.84(\mathrm{~s}, 8 \mathrm{H}), 7.35,7.45$ and $7.60(\mathrm{~m}, 36 \mathrm{H}), 7.84$ $(\mathrm{s}, 4 \mathrm{H})$. MS $(70 \mathrm{eV}) \mathrm{m} / \mathrm{z}(\%): 912\left(8, \mathrm{M}^{+}\right), 359(82), 180(100)$.

$4^{\prime}, 5^{\prime}$-Bis(bromomethyl)-1,2-benzo[2.2]paracyclophan-1-ene (13). A solution of $320 \mathrm{mg}(0.86 \mathrm{mmol})$ of $12 \mathrm{e}$ in $20 \mathrm{~mL}$ of dry THF was added dropwise to a suspension of $100 \mathrm{mg}(2.6 \mathrm{mmol})$ of LAH in $40 \mathrm{~mL}$ of THF at $0^{\circ} \mathrm{C}$. The mixture was allowed to warm up to room temperature, stirred for $1 \mathrm{~h}$, and was hydrolyzed with $10 \mathrm{~g}$ of ice. The solvent was removed in vacuo and the white residue purified by flash chromatography on $30 \mathrm{~g}$ of silica gel (ethyl acetate/dichloromethane $1: 10, R_{f}=0.01$ ), yielding $230 \mathrm{mg}(85 \%)$ of $4^{\prime}, 5^{\prime}$-bis(hydroxymethyl)-1,2-benzo[2.2]paracyclophan-1-ene, $\mathrm{mp} 221^{\circ} \mathrm{C}$. IR $(\mathrm{KBr}): \nu 3290(\mathrm{OH}) \mathrm{cm}^{-1}$. ${ }^{1} \mathrm{H}$ NMR (270 MHz, $\left.\mathrm{CDCl}_{3}\right): \delta 2.89(\mathrm{~s}, 2 \mathrm{H}, \mathrm{OH}), 3.11(\mathrm{~s}, 4 \mathrm{H}, \mathrm{H}-9,10)$, $4.91(\mathrm{~s}, 4 \mathrm{H}, \mathrm{H}$-benzyl), 6.53 (AB system, $8 \mathrm{H}, \mathrm{H}$-arene of paracyclophane), $7.62(\mathrm{~s}, 2 \mathrm{H}) .{ }^{13} \mathrm{C} \mathrm{NMR}\left(68 \mathrm{MHz}, \mathrm{CDCl}_{3}\right): \delta 35.68(-), 62.96$ $(-), 126.79(+), 133.38(+), 133.49(+), 138.85\left(C_{\text {quat }}\right), 140.63\left(\mathrm{C}_{\text {quat }}\right)$, $141.52\left(\mathrm{C}_{\text {quat }}\right)$. MS $(70 \mathrm{eV}) \mathrm{m} / \mathrm{z}(\%): 316\left(79, \mathrm{M}^{+}\right)$.

To a suspension of $210 \mathrm{mg}(0.66 \mathrm{mmol})$ of $4^{\prime}, 5^{\prime}$-bis(hydroxymethyl)1,2-benzo[2.2]paracyclophan-1-ene in $20 \mathrm{~mL}$ of dry benzene was added 
at room temperature $450 \mathrm{mg}(1.7 \mathrm{mmol}, 1 \%$ solution in benzene) of phosphorus tribromide, and the mixture was stirred for $12 \mathrm{~h}$. The reaction mixture was poured onto $200 \mathrm{~g}$ of ice, diluted with $150 \mathrm{~mL}$ of diethyl ether, and extracted with four portions of $50 \mathrm{~mL}$ of water. The organic phase was dried over $\mathrm{MgSO}_{4}$ and the solvent evaporated in vacuo Chromatography on $30 \mathrm{~g}$ of silica gel (ethyl acetate/dichloromethane $\left.1: 10, R_{f}=0.69\right)$ yielded $130 \mathrm{mg}(44 \%)$ of $13, \mathrm{mp} 252{ }^{\circ} \mathrm{C}$. IR (KBr): v $3070,1600,1500 \mathrm{~cm}^{-1}$. ${ }^{1} \mathrm{H}$ NMR (270 MHz, CDCl $): \delta 3.12(\mathrm{~s}, 4 \mathrm{H}$, $\mathrm{H}-9,10), 4.80$ (s, 4 H, H-benzyl), 6.55 (AB system, $\delta_{\mathrm{A}}=6.58, \delta_{\mathrm{B}}=6.51$, ${ }^{3} \mathrm{~J}=8 \mathrm{~Hz}, 8 \mathrm{H}, \mathrm{H}$-arene of paracyclophane $), 7.60(\mathrm{~s}, 2 \mathrm{H}),{ }^{13} \mathrm{C} \mathrm{NMR}$ $\left(100 \mathrm{MHz}, \mathrm{CDCl}_{3}\right): \delta 30.10(-), 34.63(-), 128.44(+), 132.22(+)$, $132.36(+), 135.03\left(\mathrm{C}_{\text {quat }}\right), 138.69\left(\mathrm{C}_{\text {quat }}\right), 139.50\left(\mathrm{C}_{\text {quat }}\right), 146.96\left(\mathrm{C}_{\text {quat }}\right)$. MS (70 eV) $m / z(\%): 444 / 442 / 440\left(26 / 51 / 27, \mathrm{M}^{+}\right), 283(100)$.

$5^{\prime}, 6^{\prime}$-Dicarbethoxy-4',5',6', '-tetrahydro-1,2-naphtho[2.2]paracy clophan1-ene (15). A mixture of $80 \mathrm{mg}(0.18 \mathrm{mmol})$ of $13,249 \mathrm{mg}(0.23 \mathrm{~mL}$, $1.45 \mathrm{mmol}$ ) of diethyl maleate, and $980 \mathrm{mg}$ (15 mmol) of activated zinc ${ }^{27}$ in $8 \mathrm{~mL}$ of dry dioxane was sonicated at room temperature for $16 \mathrm{~h}$. The reaction mixture was filtered, diluted with $250 \mathrm{~mL}$ of dichloromethane, washed with $100 \mathrm{~mL}$ of saturated $\mathrm{NH}_{4} \mathrm{Cl}$ and $100 \mathrm{~mL}$ of water, dried over $\mathrm{MgSO}_{4}$, and evaporated in vacuo. The residue was recrystallized from toluene/heptane (1:3), yielding $37 \mathrm{mg} \mathrm{(45 \% )} \mathrm{of} 15, \mathrm{mp} 175^{\circ} \mathrm{C}$. IR $(\mathrm{KBr}): \nu 1730(\mathrm{C}=\mathrm{O}) \mathrm{cm}^{-1}$. ${ }^{1} \mathrm{H}$ NMR $\left(400 \mathrm{MHz}, \mathrm{C}_{6} \mathrm{D}_{6}\right): \delta 1.02(\mathrm{t}$, $\left.6 \mathrm{H}, \mathrm{CH}_{3}\right), 2.79(\mathrm{~s}, 4 \mathrm{H}, \mathrm{H}-9,10), 2.90(\mathrm{~m}, 2 \mathrm{H}), 3.08(\mathrm{~m}, 2 \mathrm{H}), 3.21$ $(\mathrm{m}, 2 \mathrm{H}), 4.02\left(\mathrm{q}, 4 \mathrm{H}, \mathrm{OCH}_{2}\right), 6.45\left(\mathrm{AB}\right.$ system, $\delta_{\mathrm{A}}=6.55, \delta_{\mathrm{B}}=6.35$, ${ }^{3} J_{\mathrm{AB}}=7.5 \mathrm{~Hz}, 8 \mathrm{H}, \mathrm{H}$-arene of paracyclophane $), 7.23(\mathrm{~s}, 2 \mathrm{H}) .{ }^{13} \mathrm{C}$ NMR (100 MHz, $\left.\mathrm{CDCl}_{3}\right): \delta 14.21\left(+, \mathrm{CH}_{3}\right), 31.66\left(-, \mathrm{OCH}_{2}\right), 34.62$ $(-, C-9(10)), 42.31(+), 60.63(-), 125.61(+), 132.19(+), 132.33(+)$, $132.37\left(\mathrm{C}_{\text {quat }}\right), 139.25\left(\mathrm{C}_{\text {quat }}\right), 139.68\left(\mathrm{C}_{\text {quat }}\right), 143.64\left(\mathrm{C}_{\text {quat }}\right), 174.40\left(\mathrm{C}_{\text {quat, }}\right.$ $\mathrm{C}=\mathrm{O})$. MS (70 eV) $\mathrm{m} / \mathrm{z}(\%): 454\left(100, \mathrm{M}^{+}\right)$. Anal. Calcd for $\mathrm{C}_{30} \mathrm{H}_{30} \mathrm{O}_{4}: \mathrm{C}, 79.31 ; \mathrm{H}, 6.60$. Found: $\mathrm{C}, 78.71 ; \mathrm{H}, 6.64$.

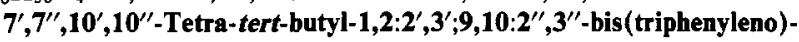
[2.2]paracyclophane-1,9-diene (16). A solution of $30 \mathrm{mg}(0.04 \mathrm{mmol})$ of $1 \mathrm{~h}$ and $20 \mathrm{mg}(0.08 \mathrm{mmol})$ of iodine in $20 \mathrm{~mL}$ of benzene was irradiated in a quartz tube under nitrogen with a 250-W $\mathrm{Hg}$ medium-pressure lamp for $24 \mathrm{~h}$. The white precipitate was removed by filtration, washed with $10 \mathrm{~mL}$ of hexane, and dried in vacuo, to yield $20 \mathrm{mg}(66 \%)$ of $16, \mathrm{mp}$ $>290^{\circ} \mathrm{C}$. ${ }^{1} \mathrm{H} \mathrm{NMR}\left(250 \mathrm{MHz}, \mathrm{CDCl}_{3}\right): \delta 1.39\left[\mathrm{~s}, 36 \mathrm{H}, \mathrm{C}\left(\mathrm{CH}_{3}\right)_{3}\right]$, $6.67\left(\mathrm{~s}, 8 \mathrm{H}, \mathrm{H}\right.$-arene of paracyclophane), 8.24 (ABX system, $\delta_{\mathrm{A}}=8.71$, $\delta_{\mathrm{B}}=8.68, \delta_{\mathrm{X}}=7.77,{ }^{3} J_{\mathrm{BX}}=8.0 \mathrm{~Hz}, 12 \mathrm{H}, \mathrm{H}$-arene $), 8.91(\mathrm{~s}, 4 \mathrm{H})$.

$4^{\prime}, 5^{\prime}$-Bis (p-(bromomethyl)phenyl) - 1,2-benzo[ 2.2]paracyclophan-1ene (17). A solution of $143 \mathrm{mg}(0.27 \mathrm{mmol})$ of $12 \mathrm{i}$ in $100 \mathrm{~mL}$ of dry THF was added dropwise to a suspension of $40 \mathrm{mg}(1.1 \mathrm{mmol})$ of $\mathrm{LAH}$ in 80 $\mathrm{mL}$ of THF at $0^{\circ} \mathrm{C}$. The reaction mixture was allowed to warm to room temperature and stirred for $1 \mathrm{~h}$. After hydrolysis with $20 \mathrm{~g}$ of ice, the mixture was extracted with $100 \mathrm{~mL}$ of chloroform, the organic phase was dried over $\mathrm{MgSO}_{4}$ and evaporated to dryness, and the solid residue was subjected to chromatography on $50 \mathrm{~g}$ of silica gel (dichloromethane/ ethyl acetate $\left.10: 1, R_{f}=0.1\right)$, yielding $75 \mathrm{mg}(60 \%)$ of $4^{\prime}, 5^{\prime}$-bis $(p$ - (hydroxymethyl)phenyl)-1,2-benzo[2.2]paracyclophan-1-ene, $\mathrm{mp}>290$ ${ }^{\circ} \mathrm{C}$. ${ }^{1} \mathrm{H}$ NMR $\left(270 \mathrm{MHz}, \mathrm{CDCl}_{3}\right): \delta 1.60(\mathrm{~b} \mathrm{~s}, 2 \mathrm{H}, \mathrm{OH}), 3.10(\mathrm{~s}, 4 \mathrm{H}$, $\mathrm{H}-9,10$ ), 4.62 (b s, $4 \mathrm{H}, \mathrm{CH}_{2} \mathrm{O}$ ), 6.58 (AB system, $\delta_{\mathrm{A}}=6.62, \delta_{\mathrm{B}}=6.56$, ${ }^{3} J_{\mathrm{AB}}=8.0 \mathrm{~Hz}, \mathrm{H}$-arene of paracyclophane), $7.35\left(\mathrm{AB}\right.$ system, $\delta_{\mathrm{A}}=7.38$, $\delta_{\mathrm{B}}=7.30,{ }^{3} J_{\mathrm{AB}}=8.0 \mathrm{~Hz}, \mathrm{H}$-phenyl), $7.60\left(\mathrm{~s}, 2 \mathrm{H}, \mathrm{H} \cdot 3^{\prime}, 6^{\prime}\right)$

To a suspension of $70 \mathrm{mg}(0.15 \mathrm{mmol})$ of $4^{\prime}, 5^{\prime}$-bis (p-(hydroxymethyl)phenyl)-1,2-benzo[2.2] paracyclophan-1-ene in $10 \mathrm{~mL}$ of benzene was added at $0^{\circ} \mathrm{C} 2 \mathrm{~mL}(0.2 \mathrm{mmol}, 0.1 \mathrm{M}$ solution in benzene $)$ of phosphorus tribromide. The mixture was allowed to warm up to room temperature and stirred for $12 \mathrm{~h}$. Water $(0.5 \mathrm{~mL})$ was added, the solution was dried over $\mathrm{MgSO}_{4}$, and the solvent was evaporated to dryness. The solid residue was chromatographed on $25 \mathrm{~g}$ of silica gel (dichloromethane/hexane 1:1, $\left.R_{f}=0.39\right)$, yielding $73 \mathrm{mg}(82 \%)$ of $17, \mathrm{mp}>290^{\circ} \mathrm{C}$. ${ }^{1} \mathrm{H}$ NMR $(270$ $\left.\mathrm{MHz}, \mathrm{CDCl}_{3}\right): \delta 3.12(\mathrm{~s}, 4 \mathrm{H}, \mathrm{H}-9,10), 4.49\left(\mathrm{~s}, 4 \mathrm{H}, \mathrm{CH}_{2} \mathrm{Br}\right), 6.60(\mathrm{AB}$ system, $\delta_{\mathrm{A}}=6.62, \delta_{\mathrm{B}}=6.57,{ }^{3} J_{\mathrm{AB}}=8.4 \mathrm{~Hz}, 8 \mathrm{H}$, H-arene of paracyclophane), 7.27 (AB system, $\delta_{\mathrm{A}}=7.30, \delta_{\mathrm{B}}=7.23,{ }^{3} J_{\mathrm{AB}}=8.4 \mathrm{~Hz}$, $8 \mathrm{H}, \mathrm{H}$-phenyl), 7.65 (s, $\left.2 \mathrm{H}, \mathrm{H}-3^{\prime}, 6^{\prime}\right) .{ }^{13} \mathrm{C}$ NMR (68 $\mathrm{MHz}, \mathrm{CDCl}_{3}$ ): $\delta 33.26(-), 34.96(-), 127.96(+), 128.79(+), 130.39(+), 132.36(+)$, $132.45(+), 136.24\left(\mathrm{C}_{\text {quat }}\right), 138.27\left(\mathrm{C}_{\text {quat }}\right), 139.45\left(\mathrm{C}_{\text {quat }}\right), 139.71\left(\mathrm{C}_{\text {quat }}\right)$, $141.47\left(C_{\text {quat }}\right), 145.39\left(C_{\text {quat }}\right)$. MS $(70 \mathrm{eV}) \mathrm{m} / z(\%): 596 / 594 / 592$ $\left(44 / 100 / 49, \mathrm{M}^{+}\right)$. Anal. Calcd for $\mathrm{C}_{34} \mathrm{H}_{26} \mathrm{Br}_{2}: \mathrm{C}, 68.70 ; \mathrm{H}, 4.41 ; \mathrm{Br}$, 26.89. Found: C, $68.33 ; \mathrm{H}, 4.38 ; \mathrm{Br}, 26.48$.

1,2:4,5-Bis([2.2]paracyclophan-1-eno)benzene (18). A suspension of $100 \mathrm{mg}(0.17 \mathrm{mmol})$ of $17 \mathrm{in} 100 \mathrm{~mL}$ of diethyl ether was added dropwise over $1 \mathrm{~h}$ at room temperature to a solution of $1.2 \mathrm{mmol}$ of phenyllithium in $20 \mathrm{~mL}$ of diethyl ether. Water $(1 \mathrm{~mL})$ was added, the solvent was evaporated in vacuo, and the solid residue was chromatographed on 25 $\mathrm{g}$ of silica gel (dichloromethane/hexane 1:1). Fraction I $\left(R_{f}=0.95\right)$ : biphenyl, not isolated. II $\left(R_{f}=0.80-0.85\right): 22 \mathrm{mg}$ of an unidentified product mixture. III $\left(R_{f}=0.58-0.68\right): 24 \mathrm{mg}$ of three compounds. Separation by preparative thin-layer chromatography (dichloromethane/ hexane 1:1) afforded $8 \mathrm{mg}(11 \%)\left(R_{f}=0.68\right)$ of $18 .{ }^{1} \mathrm{H}$ NMR $(270$ $\mathrm{MHz}, \mathrm{CDCl}_{3}$ ): $\delta 3.13(\mathrm{~s}, 8 \mathrm{H}), 6.64\left(\mathrm{AB}\right.$ system, $\delta_{\mathrm{A}}=6.69, \delta_{\mathrm{B}}=6.59$, ${ }^{3} J_{\mathrm{AB}}=8.0 \mathrm{~Hz}, 16 \mathrm{H}, \mathrm{H}$-arene of paracyclophane), $7.79(\mathrm{~s}, 2 \mathrm{H}, \mathrm{H}$-arene). $\mathrm{MS}(70 \mathrm{eV}) \mathrm{m} / z(\%): 434\left(100, \mathrm{M}^{+}\right)$. Anal. Calcd for $\mathrm{C}_{34} \mathrm{H}_{26}: 434.2035$. Found: 434.2032 (MS).

Acknowledgment. This work was supported by the VolkswagenStiftung, the Deutsche Forschungsgemeinschaft, the Schweizerischer Nationalfonds zur Förderung der wissenschaftlichen Forschung, the Fonds der Chemischen Industrie, BASF AG, Hoechst AG, Bayer AG, and Degussa AG. O.R. and B.K. thank the Studienstiftung des Deutschen Volkes for a doctoral fellowship, O.R. thanks the Minerva foundation for a young scientists' travel award. We thank Dr. B. Knieriem for his careful revision of the manuscript. 